ACTIVISM AND ABDICATION ON THE INSIDE: THE EFFECT OF EVERYDAY PRACTICE ON CORPORATE RESPONSIBILITY

\author{
Michal Carrington \\ Department of Management and Marketing, University of Melbourne \\ Michal.Carrington@unimelb.edu.au
}

Detlev Zwick

Schulich Business School, York University

dzwick@schulich.yorku.ca

\title{
Benjamin Neville
}

Department of Management and Marketing, University of Melbourne banevi@unimelb.edu.au

\section{CONFLICT OF INTEREST:}

Michal Carrington declares that she has no conflict of interest. Benjamin Neville is a section co-editor for the 'Corporate Responsibility: Theoretical/Qualitative Issues' section in the Journal of Business Ethics. Detlev Zwick declares that he has no conflict of interest. 


\title{
Running Head:
}

Activism and Abdication on the Inside

Title:

Activism and Abdication on the Inside: The Effect of Everyday Practice on Corporate Responsibility

\begin{abstract}
While mainstream CSR research has generally explored and argued for positive ethical, social and environmental performance, critical CSR scholars argue that change has been superficial—at best, and not possible in any substantial way within the current capitalist system. Both views, however, only address the role of business within larger systems. Little attention has been paid to the everyday material CSR practice of individual managers. We go inside the firm to investigate how the micro-level acts of individual managers can aggregate to drive transformation of the macro-level business logic. We draw on the strategy-aspractice approach to organize our research. The study reveals two orientations towards the integration of personal ethics into the workplace: abdication and activism. These orientations are supported by managerial practice such as reproductive and coping tactics (abdication) and covert and overt tactics (activism); and, three enabling conditions of activist practice: empowerment and psychological safety, moral shock, and morality praxis. While our findings illustrate the tremendous challenges managers face when attempting to influence organizational practices towards their ethical and environmental aspirations, we also show that under specific conditions, individual managers can become fully engaged advocates and drivers of positive change from the inside. In so doing, our individual-level analysis of intrapreneurship provides a more complex picture of the possibilities for positive change than have been previously put forth by mainstream and critical CSR research.
\end{abstract}

\section{Key Words:}

Business Transformation, CSR Legitimacy Crisis, Empowerment, Managerial Activism, Individual-Level CSR, Business Activists, Social Intrapreneurs, Social Change Agents, Moral Abdication, Moral Shock, Moral Praxis, Psychological Safety, Strategy-as-Practice. 


\section{Activism and Abdication on the Inside: The Effect of Everyday Practice on Corporate Responsibility}

Capitalism continues to produce increasingly severe social, economic, and environmental consequences (IMF 2015; Piketty 2014; UNFCCC 2015). The inability of current corporate social responsibility (CSR) practice to abate these concerning externalities of the economic system has placed the legitimacy of CSR under strain (Fleming and Jones 2012; Scherer et al. 2016; Wright and Nyberg 2015). This CSR legitimacy crisis (Fleming and Jones 2012) has triggered a range of responses from scholars and practitioners. Some critical management theorists view current CSR practice, in particular the instrumental view that focuses on the business case for CSR, as: a barrier to positive sustainability progress; a distraction or smoke screen to hide inconvenient truths behind; and at worst, a Trojan horse that is intensifying ecological, economic, and social crises by enabling corporations to carry-on with business as usual through stealth (Banerjee 2008, 2011; Blowfield 2005; Bondy, Moon, and Matten 2012; Carrington, Zwick, and Neville 2016; Doane 2005; Fleming and Jones 2012; Iivonen and Moisander 2015; Szmigin and Rutherford 2013; Wright and Nyberg 2015).

In contrast, Paul Polman, Unilever Global CEO, suggests that, "We have never had a better opportunity to eradicate poverty and at the same time achieve a more sustainable future. Future generations will not forgive us if we fail to act. Business has to be part of the solution...It only takes a handful of sizable companies to reach tipping point and to transform markets - and that is exactly what we are trying to achieve" . From this perspective, the only feasible option to keep the negative consequences of the current economic system in check is through mechanisms within the system of capitalism itself: change driven from the inside.

\footnotetext{
${ }^{1}$ http://www.cgdev.org/article/unilever-ceo-paul-polman-wins-commitment-development-award-globalleadership-efforts-reduce
} 
This perspective aligns with mainstream business thinkers and practitioners who maintain a positive stance towards CSR, emphasising the 'win: win' notion of the business case for CSR (Carroll and Shabana 2010; Donaldson and Preston 1995; Orlitzky, Schmidt, and Rynes 2003) where firms can increase profitability and growth while simultaneously reducing harms and increasing value for social and environmental stakeholders (Barton 2011; Crocker and Linden 1998; Porter and Kramer 2011).

Mainstream views of CSR advocate that positive change can happen within the system, while more critical perspectives of CSR suggest that this is not possible. When we look at both sides of this scholarly debate, however, we find that the focus is overwhelmingly on business organisations' relationship with their environment, stakeholders and institutions. There has been little attention paid to how managers' individual actions and interactions inside the firm underpin, challenge and transform a business organisation's CSR practices (Aguinis and Glavas 2012; Gond et al. 2012; Maak, Pless, and Voegtlin 2016; Scherer et al. 2016). CSR is generally viewed as a firm-level response to stakeholder expectations and pressures (Harrison, Bosse, and Phillips 2010; Jones, Felps, and Bigley 2007) or the strategic practice of power aimed at reducing democratic and legal control (Banerjee 2011; Fleming and Jones 2012). In both cases, business organisations are predominantly presented as a singular and self-interested agent - with a monolithic worldview, singular strategy, and uniform practices and belief systems - and its managers as singular, homogenous teams (Clegg and Higgins 1987; Felin, Foss, and Ployhart 2015; Geppert and Dörrenbächer 2014). This prevalent view presents a significant barrier to fully understanding the potential forces of change within business organisations (Weitzner and Deutsch 2015). Taking the firm as the unit of analysis obscures the importance of heterogeneous individual actors in driving change both at a company and societal level. This raises an interesting question regarding whether positive change can emerge from within the capitalist system: can individual managers 
transform businesses from the inside, and thus make business a facilitator of an equitable and sustainable system of provision? And if so, under what conditions do managers become agents of transformation?

Multiple units of analysis have been considered in the study of CSR: individual firms; industry-level; and community, regional, societal, national, and global level (Banerjee, 2011). Yet, our understanding of the micro-practices at a personal, individual level inside the firm remains thin (Aguinis and Glavas 2012; Gond et al. 2012). Nevertheless, we identify an emerging literature on the experiences and actions of these 'social intrapreneurs' or 'social change agents' who attempt to influence their firm to become more socially responsible or sustainable ${ }^{2}$. Management scholars have made several important identity-based (e.g. Brickson, 2000, 2013; Hemingway, 2005; Meyerson and Scully, 1995; Wright et al., 2012) and strategic contributions (Alt and Craig 2016; Briscoe and Gupta 2016; Heinze and Weber 2016; Sonenshein 2016; Wickert and de Bakker 2016) to the field's understanding of how managers experience value conflict and attempt to affect social change in for-profit organizations (Bansal 2003; Sharma 2000). When concerned with insider activism, these studies focus largely on two aspects of the social intrapreneur: (1) identity construction in response to value conflict; and (2) the identification of processes (defined broadly, including management systems, organizational values, coordinating various functional actors, etc.) used by social change agents to transform the organization (e.g. Acquier, Daudigeos, and Valiorgue 2011; Alt and Craig 2016; Courpasson, Dany, and Clegg 2012; Weitzner and Deutsch 2015).

While much can be learned from this work, we identify two blind spots in the literature on social intrapreneurship that our study aims to address. First, little is known about

\footnotetext{
2 We use the terms 'social intrapreneurs' and 'activists' interchangeably. While the term 'social intrapreneurs' is gaining academic momentum, a number of study informants used the in vivo term 'activists' to describe their own practices and managerial approach.
} 
the context and conditions that underpin the value and identity conflict experienced by social intrapreneurs. In our study, we begin to shed light on this important question, suggesting that context plays a central role in what we call the activation of internal social, moral and ethical activism. Importantly, in this paper we are more interested in exploring the emergence of social intrapreneurs through practice, rather than identity, because our fundamental motivation is to understand whether diffused micro-actions and -practices can affect how organizations 'do' responsible business. Second, extant research on social intrapreneur identities and strategic activism tends to focus on salient actors in the organization, such as champions and vocal managers who aspire to be change agents and actors in positions of influence (e.g., upper management, designated sustainability personnel, etc.) (see e.g., Andersson and Bateman, 1997; Howard-Grenville 2007; Weitzner and Deutsch 2015). In our study, we focus on managers across multiple hierarchical levels of organisations - lower, mid and senior/CEO levels, to offer a more comprehensive picture about who might engage in internal activism and what such social intrapreneurship might look like at the everyday level of practice.

While there is no such thing as a cohesive and unifying practice theory (Reckwitz 2002; Warde 2005), a practice theoretical approach aims at explaining and understanding action by taking into consideration the cultural and social context of the action (Bourdieu, 1977; Giddens, 1984). In the social sciences, the common label of 'practice theory/theorist' is applied to a diverse set of thinkers - e.g., Bourdieu, Giddens, Latour, Schatzki, Foucault and others - who share an interest in the 'everyday' and 'life-world'. Thus, practice theorists are influenced by the interpretative or cultural turn in social theory as they attempt to analyse within practice the relations between agency, knowledge and understanding (see also Orlikowski, 2002). Similarly, our study investigates the conditions of agency, moments of understanding and events that affect the ability of individual managers to act - and his or her 
knowledge about how to act - inside the organization in ways that reflect personal aspirations for a more sustainable and fair economic system. Thus, we investigate CSR and normative ethics not as abstract objects of strategic, economic, or political relevance, but as individualized and personalized objects of struggle, concern and negotiation in the everyday work lives of managers.

Our focus is what Hatch and Schultz (2017) call "micro-level activities" that account for how and why actors decide, or not decide, to enact activist practices. By going inside the organization, we are able to show some of the complexity affecting organizational change towards responsible business. In doing so, we investigate three research questions. First, we ask: how do managers practice social and moral activism in their organizational roles, and how does this activist practice contrast with the practice of non-activist managers?

Understanding the contrasts and commonalities in relevant practices between activist and non-activist managers is necessary to respond to our second research question: what contexts, conditions and triggers foster the emergence of activist managers in organizations? This research question is imperative to understanding how managers become social and moral activists in the workplace. Finally, we ask: how can diffused micro-practices of social and moral intrapreneurs influence organizational-level practices and ethos?

Drawing on rich interview data collected in 27 in-depth interviews with managers from a range of organisations, we highlight the heterogeneous strategies and tactics developed by often less visible and prominent actors as they attempt to become more activist and influential within their respective sphere of influence (Courpasson, et al., 2012). Echoing some of the findings by Orlikowski in her 2002 study of engineers, staff, managers and senior executives collaborating across a distributed organization towards new product development, we suggest that practices of social intrapreneurship and moral and ethical activism are widely diffused throughout the organization and performed in various ways by many different actors. 
However, while Orlikowski (2002) emphasizes the purposefully coordinated nature of practices of sharing, learning and doing across distributed actors to effectuate strategic organizational capabilities (such as new product development), we are interested in practices that are, for various reasons, not (yet) anchored in structured organizational processes. Methodologically, we therefore emphasize practices as enacted by specific actors - such as clearly identifiable champions and intrapreneurs - rather than embedded in structures, policies and processes.

By studying social intrapreneurs at the level of everyday material practice of managers we find that much activist practice in the organization is located across different decision-making levels and performed in often unorganized, uncoordinated and strategically unstructured ways. And yet, we also find evidence that this kind of diffused activism of individual managers can catalyse change and establish new practices at the meso and macro business levels; that is, evidence of positive change emerging from within the capitalist system. These micro-level acts can "cumulatively bubble up and implicate organized actors, creating a groundswell for change at the field level" (Ansari and Phillips 2011). Thus, a more comprehensive understanding of the role of individual managers as social intrapreneurs should provide us with a more accurate picture of how everyday managerial decisions might impact social, economic, and environmental sustainability at an aggregate level. Hence, in this study we begin to address these gaps in the CSR literature by opening the 'black box' of the firm. Our analysis identifies four etic categories of practice - reproductive practice, coping tactics, covert tactics, and overt tactics ${ }^{3}$. Based on this practice, we identify two distinct orientations towards the integration of ethics in the workplace that we label

\footnotetext{
${ }^{3}$ Aligned with the Strategy-as-Practice approach, we define practice to encapsulate the activities of actors/practitioners (Jarzabkowski et al, 2007). Thus, we use the terms action, interaction, behavior, activity, tactic and practice throughout to represent the various forms of managerial practice- "what managers do" (Johnson, Melin and Whittington, 2003, 15). Three of the four categories of practice identified in our analysis are specifically termed 'tactics' to reflect the individual-level strategic motives underpinning these forms of managerial practice.
} 
abdication and activism and develop the notion of enabling conditions of activist practice to theorise why some managers become activists while others do not. The three underlying conditions that enable the activist practice observed in our study include: empowerment and psychological safety, moral shock and morality praxis.

In what follows, we first present the identity-based literature that recognises managers' values can conflict with the organisation that we build upon to develop our research agenda. We then briefly outline the strategy-as-practice approach (Jarzabkowski 2004) to develop an enabling conceptual lens to frame our study. We then describe the methodology we adopted to investigate this line of enquiry, and present the findings of the study as we return to theory to respond to our research question.

\section{THEORETICAL BACKGROUND}

In this paper, we answer a growing call for research on the actions of and interactions between individual managers that constitutes CSR in practice (Aguinis and Glavas 2012; Gond et al. 2012; Maak et al. 2016; Scherer et al. 2016). Specifically, we focus on how managerial practices can catalyse transformation of meso- and macro-level practice. Thus, our interest is in observing what individuals do, not what firms do, in relation to ethics and responsibility in the corporate context. In this study, we build on existing work on the role of identity construction in CSR, as well as the role of strategy in creating change. We extend this literature by focusing on the practice of activist managers, and the conditions and contexts that bring about the emergence of these activist managers in an organization.

\section{Activism as Practice}


The extant literature has examined how individual managers experience and navigate situations of value conflict with their firm from an identity perspective. For the most part, these studies reveal the conflicts, incoherence, and tensions arising when business decisions and activities clash with managers' own sense of ethics or values, and the coping strategies that these individuals deploy to manage these day-to-day tensions in the workplace (e.g. Phillips, 2012; Meyerson and Scully, 1995). For instance, Wright et al. (2012) investigated workplace identity conflicts of sustainability managers and consultants who wield enhanced legitimacy within the firm to express their ideals and enact change. These managers developed different identities that they were able to employ at different times with different audiences: the win: win 'green change agent', the business-minded 'rational manager', and the confrontational 'committed activist'. This identity plasticity, however, can encourage personal conflict, and so these managers also adopted different narrative genres to explain the plasticity and form a coherent identity for themselves. These included career 'achievement', personal 'transformation', personal 'sacrifice' and 'adversity'.

Similarly investigating the strategies individuals use in response to the identity conflict between their values and their organisation, Phillips (2012) and Allen et al. (2015) found that individuals are able to cope with identity conflict by using the discursive strategies of 'distancing' themselves from the problem and 'deflecting' responsibility for the problem onto others, such as consumers or government. Allen et al. (2015) took this further to show how senior managers in the energy and power industry were not concerned about the apparent contradictions in their identities, using different identities to distance and deflect responsibility for sustainability issues away from themselves and their business organisations. While these studies are important for understanding the processes of identity construction and impression management (Goffman 1959) of managers in corporate environments, they 
generally ignore the level of practice while focusing upon process. In our study, we focus on the managerial practices (ethical and responsible or not) of individual actors.

In addition to this identity-based CSR research, we draw on the literature on managerial change strategies and tactics. Meyerson and Scully (1995) described the tentative state of their 'tempered radicals' who maintain dual commitments to both their organisation and to a social cause to cope with conflicting ethics and values. These tempered radicals adopted a number of tactics to achieve their desired change in their organisation, including focusing on small rather than big wins, acting authentically to role model the desired change, deconstructing and reconstructing language for strategic purposes, and maintaining outside affiliations to protect against co-optation from the organisation. More recently, Briscoe and Gupta (2016) provide a structural framework for understanding the advantages and disadvantages of 'insider' activists in comparison from those outside the firm. The dominant approach in recent work on social intrapreneurs' strategic approaches, however, has investigated their strategic use of discursive content, or 'issue selling'. For example, Wickert and de Bakker (2016) identify how issue sellers strategically build relationships with their targeted issue buyers to help overcome resistance. Similarly, Sonenshein (2016) provides a strategic framework for matching varying types of issue with a particular meaning-making tactic. Also considering managerial assessment of specific morally-charged issues, Weitzner and Deutsch (2015) conceptualize how the prioritization and influence of specific stakeholders on the attitudes of morally-motivated decision-makers is contingent on a range of stakeholder attributes - such as moral legitimacy, normative and coercive power, and issue urgency. Two groups of researchers have drawn on the institutional logics perspective. Heinze and Weber (2015) observed social change agents opportunistically creating and strengthening organisational "free spaces" where their new favoured logic could thrive, and then using this to infiltrate the broader organisation. Meanwhile, Alt and Craig (2016) 
identify the issue selling strategy of constructing a composite logic comprised of the firm's and of the individual/s targeted.

We are similarly interested in how managers attempt to resolve their value conflict by strategically changing the firm to their liking. We focus on how managers construct practices and the conditions under which practices for more radical change become possible.

Notwithstanding the important contribution that studies on identity construction and strategies of engagement make to our understanding of the symbolic meaning and cognitive mechanisms underpinning aspects of ethically-based decision making, these studies fall short of examining the material practices of managers and the implications of often distributed micro-level activities (Hatch and Schultz, 2017) on transformation of macro-level business practices. While studies of identity and meaning construction reveal how individuals cognitively give meaning to the world, practice approaches focus on how material acts and interactions "make the world" (Leonardi and Barley 2008). As Orlikowski (2002) suggests, the practice turn in organizational and managerial studies has arisen with an acknowledgement of the "essential role of human action in knowing how to get things done in complex organizational work" ( $\mathrm{p} 249$ ). Thus, from the vantage point of practice theory a gap exists in our understanding of how unorganized and diffused activities of individual managers can cumulatively work to 're-make the world' at the organizational level. In addition, we need to develop a better understanding of the conditions that foster activist practices inside the organization. We address this gap by posing three research questions. First, how do managers practice social and moral activism in their organizational roles, and how does this activist practice contrast with the practice of non-activist managers? Second, what contexts, conditions and triggers foster the emergence of activist managers in organizations? Third, how can the seemingly uncoordinated practices of individual managers aggregate to inadvertently transform macro-level business practice? 
We suggest that any attempt to assess the potential of contemporary managers to affect business ethics and responsibility must take into consideration the conditions that enable social, moral and environmental intrapreneurs and the tactics and strategies they devise to affect the organization at the level of social responsibility and ethical practices. Thus, we move the research lens from projects of cognitive coherence and identity construction to the context in which individuals become activated as social intrapreneurs and the kinds of everyday managerial practice these individuals produce as social, moral and environmental activists. This is not to say that cognition and identity do not matter. Rather, we understand moral and ethical activism as the expression, or outward manifestation, of a particular mode of being, or inner reality (Cragg 1997). From this perspective, acquiring activist values and aspiring to shape the organization in accordance with those values becomes a question of practice, tactics and, ultimately, strategy. Thus, to go beyond identity and cognitive approaches, we adopt the strategy-as-practice perspective to develop a conceptual lens that allows us to capture the linkages between the inner world of values and their outward manifestations.

\section{Strategy-as-Practice Perspectives}

Methodologically we follow Jarzabkowski’s (2004) lead and take a strategy-as-practice approach to organise our research and to identify modes of justification that managers attach to managerial practice. The strategy-as-practice approach to management and organizational research focuses on agency, action and interaction in the construction and enactment of strategy (Jarzabkowski, Balogun, and Seidl 2007). This approach views strategy "not as something a firm has but something a firm does" (Jarzabkowski, 2004). The provocative claim of strategy-as-practice scholars is that practices bring about strategy, rather than the other way around. Orlikowski (2002), also adopting a practice theoretical approach, makes a 
very similar point about organizational knowledge as a capability that organizations do not simply 'have' but rather have to constantly 'make' and 'remake' through the actors' engagement with, and metabolization of, the world in practice. Thus, the point of adopting a practice theory approach is to insist that concepts such as strategy and knowledge do not exist a priori, but are constituted in practice and are always oriented towards practical functions (see also Bourdieu, 1990).

Therefore, methodically, by drawing on various practice theory (e.g. de Certeau, 1984; Sztompka, 1991; Reckwitz, 2002), the strategy-as-practice perspective chooses to examine the tactical practice of actors, and places these micro-acts within the multiple social contexts that they operate within - such as their organization, industry, and wider society (Jarzabkowski et al, 2007). In this conception, practice refers to the activities of practitioners/actors; while practices are the routinized cognitive, behavioural, procedural, motivational and physical resources that are combined to inform practice at an individual actor level.

We are particularly interested in the strategy-as-practice perspective because it attends to the linkages between the reproduction and the adaptation of individuals' micro-practice (tactics) and the firm's macro-practices (strategy) (Jarzabkowski, 2004). Thus, following this approach enables us to theorize links between the micro-practice of individual managers and the macro-level implications of these activities on dominant business practice. Specifically, this micro-macro interplay occurs through a praxis - a clustering of various resources - that forms a focal point enabling social interconnection and collective activity between multiple actors (Jarzabkowski et al, 2007). The notion of praxis is particularly important to our study as it represents the nexus of "what is going on in society and what people are doing" (Sztompka, 1991, p 96), thus simultaneously delineating and synthesising micro and macro contexts (Sztompka, 1991; Tello-Rozas, Pozzebon and Mailhot, 2015; Jarzabkowski, 2004). 
The strategy-as-practice perspective intrinsically links macro ("what is going on in society") and micro ("what people are doing") levels of context in the adaptation of practices by perceiving a fluid interplay between individual-level practice and social movements through a praxis (Jarzabkowski, 2004). Thus, praxis is dynamic and fluid, evolving with shifts in practice at micro and macro levels (Jarzabkowski et al, 2007) ${ }^{4}$. We now take this conceptual linkage into our own empirical research.

\section{RESEARCH METHODOLOGY}

Banerjee (2011) calls for sustainability research to take an "ethnographies of resistance" approach, and we take this approach to capture the stories of individuals on the inside to view ethics and "sustainability from multiple perspectives and to imagine different paths to reach that elusive goal" (p729). Thus, we take as our starting point the lived experience of managers who are charged with envisioning, designing, coordinating, doing, and re-doing this new economic reality.

The study employs a multi-sited, multi-method qualitative approach within the business context (Marcus 1995). We combine semi-structured interviews, participant observation, and informal interviews within a single study to immerse ourselves in the workplace lives and environments of 26 informants.

\section{Research Context}

To support the multi-sited approach of our study, we recruited managerial informants from across multiple organisations, industries and countries (Marcus, 1995). We sought maximum

\footnotetext{
${ }^{4}$ In this study, we use the terminology micro-level to refer to individual/managerial level practice, meso-level to refer to team and organization level practice, and macro-level to refer to societal level practice external to the organisation (see: Dopfer, Foster and Potts; 2014) .
} 
variation across the range of firms represented and participants' managerial capacity (Miles and Huberman 2002; Thompson and Troester 2002) with a participant pool consisting of: major and minor retailers; large, medium and small production firms; multiple industries; local, national and multinational organizations; managers from the US, Australia, and the UK (Table 1). Consistent with this sampling strategy, these organisations varied in their approach to sustainability and integration of CSR ideology and initiatives into core business practices: from entrepreneurial firms that have been built on environmental sustainability and/or social equity platforms through to organisations for whom CSR was enacted through a few 'ethical' products in amongst the rest of their market offer and included as a bullet point on the company mission and in corporate public relations statements. It was from within these varying sites of commerce that we studied the everyday micro-practice of individual managers.

\section{Participants and Methods}

The recruitment process began by prioritising a range of production and retail organizations that met the maximum variation sampling frame. From here, individual managers with sufficient decision making capacity to affect business operations - defined by organizational hierarchy and positional responsibilities - while representing a range of experiences and decision-making capacities were identified and directly contacted. Contact was made by either direct email where an email address was publicly available, or via the LinkedIn professional networking site. In total, 26 managers agreed to take part in the study. These managers were embedded in various functions across their organisations, including: supply chain and operations, quality control and compliance, sales and account management, retail buying, sustainability, general management - including CEO and Managing Director level, and with a large proportion of informants from the marketing function. This is not surprising 
given the often more visible and outward facing nature of marketing practitioners, and these managers are particularly theoretically interesting due to their proximity to the consumer. Participation was entirely voluntary and no incentive was offered or provided. Pseudonyms are used to maintain the anonymity of our participants and their firms.

The interviews were conducted at the participants' sites of work, including corporate offices, retail outlets, and on the factory floor, and were one to four hours in duration. Meeting and interviewing participants at their work places facilitated natural responses within context. Interviews began with grand tour questions (McCracken 1988) to evoke detailed and participant-centric responses, and covered topics ranging from their personal sustainability and social equity concerns, their managerial decision-making, and through to the machinations of their firm. The interview questions remained semi-structured and evolved over the duration of the study as we followed interesting leads and became iteratively theoretical in our approach (Gioia, Corley, and Hamilton 2013). Each interview was recorded and transcribed, and provided a rich source of data with over 600 pages of transcript.

Observational research also occurred in the working environment of some informants. Observational techniques ranged from passive observation of corporate artefacts and clothing choices within this environment through to active observation on the retail and factory floor while shadowing participants, being taken on 'tours' behind the closed doors of corporate head offices, shadowing a participant as they conducted their daily managerial practice, and observing sites of product innovation and key decision making. In addition, observing corporate artefacts - such as achievement awards hanging on walls and the presence of recycling and compost bins (or lack of) - combined with interview data, assisted in the analysis of the organizational context.

A number of strategies were employed to ensure the quality of our data and the trustworthiness of our interpretation: (1) triangulation of the data by engaging in multiple 
data sources across multiple sites of data collection; (2) maximum variation sampling; (3) constant comparative analysis to challenge our interpretation; and (4) the adoption of an 'outsider perspective' by one of the research team members who did not directly engage in data collection and took on the role of 'devil's advocate' (Hammersley and Atkinson, 2008; Miles and Huberman, 1994; Gioia et al., 2012).

\section{INSERT TABLE 1 HERE}

\section{Data Analysis}

The multi-sourced data - interview transcripts and field notes - were read and re-read, and then open coded in the QSR NVivo software using a micro-coding technique (Corbin and Strauss 2008) in real time as the data was being collected (Hammersley and Atkinson 2007). In addition, theoretical memos were written during this process to capture re-occurring theoretical categories in the data (Corbin \& Strauss, 2008). These memos were developed and expanded as the data collection and analysis progressed. We concluded this first analytic phase at the point of theoretical repetition. The theoretical memos were then used as anchor points to cluster the micro-codes into first-order emic descriptions of practice and concepts. We then employed a process of axial coding to identify patterns across the first-order codes, enabling inductive development of higher level constructs and relationships (Corbin and Strauss, 2008). We cycled through this analytic process until the constructs and relationships were at a sufficient level of abstraction to develop theory (Corley and Gioia 2004). We then entered the second analytic phase, moving to macro-coding and analysis using a constant comparative technique to challenge and further develop these theoretical constructs and relationships until theoretical saturation had been reached (Corbin \& Strauss, 2008). 


\section{FINDINGS}

We developed the data structure illustrated in Figure 1 through systematic analysis of our rich empirical data. The first-order emic practices and concepts cluster and describe the tactics, activities and underlying conditions emerging from our data. The second-order themes represent etic categories of managerial practice: reproductive practice, coping tactics, overt tactics and covert tactics, and three underlying contexts that enable the activist practice were observed in our study: empowerment and psychological safety, moral shock, and moral praxis. We further collated these second-order themes into two aggregate orientations: (1) abdication on the inside; and (2) activism on the inside; and an aggregate category of: (3) enabling contexts of activist practice. We organise our findings section by these three aggregate categories, with the relevant second-order themes integrated within each section.

\section{INSERT FIGURE 1}

\section{Managerial Practice: Abdication and Activism on the Inside}

Focusing our analytic lens on the individuals working within public and private corporate structures, we discovered two orientations to the integration of social and environmental concerns into business decision making: (1) managers as abdicators of ethical responsibility and decision-making; and (2) managers as activists within the organization. While some informants in our study maintained positions and practices at the polar ends of these two contrasting orientations - abdicators and activists, the study also revealed hybrid activists who selectively shift between these two practice orientations. Figure 2 visually summarises the practices we observed to be common across and discrete within these managerial orientations. 


\section{INSERT FIGURE 2}

\section{Abdication on the Inside: Conscious and Unconscious}

The study revealed managers from across the spectrum of organizations in our study - from small private enterprises to large MNC's - who abdicated the responsibility of defining ethical business to their firms and of making ethical choices to the firm and the end consumer. Consider, for example, Noelle's views on the location of ethical decision making within her company:

\footnotetext{
“We've got global ethics policies. It's policed, it's patrolled, and there are ramifications for people that don't abide by the policy. We are held accountable for the decisions we make...everybody's done the training, so you have no excuse... If you're in middle management you just do what you're told and go on your merry way." [Noelle]
}

Noelle distances herself from the source of ethical decision making, suggesting that business ethics are something that are created and codified in a distant and separate head office or department somewhere else in the business, and unquestioningly followed by managers in the firm. Policy, for Noelle, represents a material site where practice is inscribed and made possible. To these informants, following the pre-defined codes and/or deferring decisions of ethics or sustainability to distant others in the business, enables them to displace moral and ethical obligation from the level of workplace practices to the level of institutional structures. Institutional ethics come to stand in for personal ethics and thus help managers rationalise potentially ethically-compromised decisions as acceptable business practice.

Similarly, some informants projected responsibility for making ethical and sustainable consumption choices to the end consumer.

"You take it with a grain of salt, basically, what people say compared to how it's going to play out" [Tiffany] 
"When a consumer becomes a shopper they don't give a shit. Basically, they really don't...Environmentally friendly, sustainable, ethical is not a differentiator when it comes to value. They will ultimately still choose a product at the lowest price that meets their needs." [Nigel]

Abdicating responsibility to the firm and projecting it on to the end consumer, as illustrated by Noelle, Tiffany, and Nigel, represented a coping practice that enabled informants to "live with" [Randall] tensions arising from inconsistencies between their personal normative ethics and concerns and their managerial decision-making. More importantly, the abdication allowed the relinquishing of the duty to act responsibly to other actors - consumers or the institution - allowing for conventional managerial decision making to continue unquestioned. Thus, while Phillips (2012) and Allen et al. (2015) suggest that individuals cope with identity conflict within the firm by distancing and deflecting ethical responsibility onto others, we find that abdication in this sense is not just, or even foremost, about identity construction and justification, but about the ability to reproduce and preserve existing practices. We also observed managers engaging in the abdication practice of externalizing locus of control to outside forces in their workplace, rhetorically rendering themselves incapable of enacting anything other than reproductive practices. For example, Rebecca tells us that when it comes to making ethical decisions about the brands she manages: "it's not my job to do that, it's out of my control. If it's not commercially viable, it's not going to happen”.

While some of our abdicating informants did express ethical concerns and internal conflict about the decisions they made at work, such as Andreas who expressed a concern about the potential impacts of marketing campaigns for the alcohol brands that he managed on vulnerable consumer groups, the felt intensity of these moral concerns was relatively low. We observe these informants, such as Andreas, performing moral decoupling, where support for some potentially problematic practices is maintained by selectively dissociating judgments of the impact of these practices from judgments of morality (Bhattacharjee, Berman and Reed, 2012). We identify these informants as conscious abdicators, and moral 
decoupling by externalizing the locus of control and dissociating moral judgements was a common coping practice for these managers.

In addition, we also observed unconscious abdicators who felt very little moral dissonance or tension between their own moral guides and their workplace decisions. What set these informants apart was their practice of compartmentalizing self and workmaintaining a boundary or distance between self-ethics and workplace ethics. For example, David notes that "top of mind for me as a consumer - buying products that have sustainable footprints", yet when it comes to his managerial domain "what I feel really good about is when I'm selling, because that's what I do - I trade and I sell'. Actively engaging in compartmentalizing practices to maintain the boundaries between inside and outside of work also enabled unconscious abdicators to maintain a sense of moral and ontological security within their organization, and to permanently morally decouple their workplace role. These managers, such as Tiffany express "no reason to doubt that the companies I have worked for behave in an ethical manner". Interestingly, while these unconscious abdicators engaged in reproductive practice, unlike our conscious abdicators however, they did not rely on coping practices as they purported to experience few moral tensions.

There were limits, however, to the extent to which some informants could decouple their normative ethical and moral concerns from the work they do for the organization. For instance, Michael illustrates these limitations when discussing a specific brand in his product portfolio that he is ethically opposed to - because of the working conditions and location of production - and yet is a key profit driver that enables him to also stock sustainable products that on their own would not be commercially viable: "I reconcile my choice of [brand]...because intellectually it has a place. Emotionally it's harder work for me”. While on the conventional level of the business case, Michael is able to justify the existence of what he sees as an ethically problematic brand in his overall product portfolio, his gut-feel emotive 
response struggles with this rationalization. Nonetheless, and importantly for our conceptual understanding of the abdicator, we find that despite clear recognition of ethical contradictions, managers such as Michael and Noelle do not consider their everyday managerial practices as a viable site for change. These experiences of ethical conflict displayed by the conscious abdicators in our study - such as Michael, Noelle and Andreas are important not only because of the implications on the intricate cognitive gymnastics required to maintain a cohesive self-image, but because these experiences of tension illustrate sites of moral conflict where, under the right conditions, these abdicators could become activists. Our findings suggest that abdication is not necessarily a permanent managerial position. We now examine the practices of the activist managers in our study, then the conditions and triggers that enable the transition from abdication to the activation of internal social, moral and ethical activism.

\section{Activism on the Inside: Permanent and Hybrid}

We also discovered managers who are unable or unwilling to abdicate ethical practice to organizational codes and ethical choice to the end consumer. These internally-driven informants engage in activism on the inside: "I grew up with a desire to do something and over time that morphed into a recognition that I wanted to change the system, you've got to get inside the system to change it, an activist in business" [Paul].

Activists on the inside are boundary workers (Carrington and Neville 2016; Williams 2002) who actively integrate their personal sense of morality, ethics and sustainability into their workplace decisions, seeking to bridge the self-work boundary and maintain a sense of authenticity across these domains. Activists aim not to decouple personal moral values and work practices. These actors consider what they do as the best expression of who they are. As Paul suggests: 
"I want to keep the sense of my integrity and self and I don't want to become something else. You know, I look at what I've achieved and all those things I've done over time is because I'm bringing me to it, I'm not trying to be them. I'm trying to be myself."

The activists on the inside in our study were guided by internal normative views of "good and morally right" [James] business decisions - in contrast to external business codes of practice, as illustrated by Melanie: "It's not for the sales...it's the right thing to do. It's the right thing to have a product line that is certified organic [and] fair-trade certified". In addition, these individuals also espouse a sense of duty or responsibility to engage in ethical and responsible decision-making within their managerial roles. For instance, in an interview Patrick explains, "I think that it is fundamental to society to [be] aware of how we can better the world we live in, how we can make it better for the people that are coming after us...I have an enormous responsibility, because of the resources I manage". Thus, these managers do not displace personal responsibility for making the sustainable/ethical choices and decisions onto other actors such as consumers or institutions. Rather, they see business as central to the solution and take this responsibility on themselves within their managerial capacity: "I have this view that if you've got the position, you've got to use it...I get active and I make sure that I'm influencing things and don't wait for that change to happen. If you want to bring about substantial change - the time has come where the greatest change is going to come from business.”[Paul].

These individuals do not sit within dedicated sustainability or CSR departments, but rather are located within central operations of the firm, such as supply chain, production, marketing, legal counsel, and general management. In contrast to abdicators, however, managers such as Paul, Patrick and Anastasia interpret their positions in the corporate structure as imbued with responsibility and agency to act. Everyday practice therefore must reflect one's beliefs. As Malcolm illustrates, the combination of internally-centred motivation 
and being embedded within a core function of the organization enables activists on the inside to enact change.

"[Sustainability] champions in the organization sit in different departments, often not actually in a sustainability team...because of their personal drive and interest they're the ones that really push beyond the scope of their role. Sustainability teams [are] not very well embedded in the organization. They tend to be quite niche within the organization, they have limited budget, limited influence. Change is driven by individuals that are in [core operations]. Whereas a lot of the sustainability teams tend to be doing sustainability reporting, and that's how they make up their time." [Malcolm]

Activists on the inside are prepared to take risks, to find novel approaches to remove obstacles, to "challenge anything, put it through the mill" [Trevor], to withstand challenges from colleagues, and to "shake things up" [Michael]. This agitation and risk taking, however, tended to be limited to the concerns and issues most salient to the individual, within their control to influence, and opportunistic. Michael and Trevor are archetypical de Certauvian agents because they operate within the power structures of the firm but also look for ways to resist the dominant narrative through managerial practice whenever possible. Put differently, activists on the inside seek to integrate specific and bounded normative ethical concerns and sustainability issues into the firm's activities and are guided by "lasting values" and "universal truths" [Paul] that they were personally "passionate about" [James, Jennifer, Anastasia].

There was significant variation, however, in how much and how often our managers were willing and felt able to engage in activist practice. The extent to which they are prepared to agitate in the open is heavily dependent on the level of power and agency they wield in their firm, and the sense of psychological safety that this brings. Some managers - such as Paul, Patrick, Anastasia and Seamus - are permanently oriented towards activism inside their businesses. What set these managers apart was their formal power and agency within their organization. This empowerment to overtly advocate for ethical concerns and moral decision 
making came about through their elevated position in the company hierarchy, and/or a culture of personal responsibility.

In situations where formal and informal agency were less abundant, however, activists need to operate more covertly and selectively. Informants such as Susan, Jennifer, James and Colin illustrate this hybrid orientation as they shift in and out of covert activist practice. These intermittent activists lack the formal hierarchical power to act in the open, yet find significant informal agency in the managerial space of everyday practice; these managers are socially connected, and understand the formal and informal decision levers within the firm and how to use them. For instance, Susan covertly influences the development of the ethical sourcing standards adopted by her firm to include her own personal sustainability concerns, and Jerome exploits his firm's concern for reputational risk to finance his unannounced visits to supplier's factories to check on working conditions and wellbeing of factory workers, and his firm's power in the supply chain to pressure "unscrupulous" suppliers to change their operating practices.

\section{Activist Practices}

Whether acting out overtly or covertly, we observed the activist managers in our study living out their moral guides through engagement in a range of overarching managerial practices (see Figure 2). These practices include the appropriation of business resources, processes and concerns; the formation and influencing of moral praxis; the instigating of 'moral shocks' in others. A key tool used by the activists on the inside to challenge the firm and enact normative change is the appropriation of 'the business case for CSR', or as Nigel suggests, the 'commercial angle'. Operating overtly or covertly, these individuals adopt business functions and tools - particularly the instrumental CSR logic - to build commercial business cases that legitimate their normative ambitions. It is under this instrumental 
commercial cloak that these activists disguise their normative ethical/sustainable motives and make practices that challenge business-as-usual appear less divergent and threatening.

Thus, to be effective in their activist attempts, these individuals had to have sufficient capacity within the firm to access data and resources to build their business cases and commercial arguments. For example, when attempting to change his business's food marketing focus on vulnerable consumers, such as children, Patrick drew upon scientific data from obesity studies, governmental nutrition guidelines, and financial modelling techniques to build a "fact-based" business case based on company reputational risk rather than "taking the higher [moral] route, the higher level". Further, Malcolm illustrates how the rhetorical business case cloak that is used to commercially legitimate sustainability decisions in one of the firms he works with is then discarded once the decision has been made to support the sustainability initiative:

"To get senior management decisions made... a commitment to invest a few million dollars in a sustainability program, they have to make sense on paper - they have to align with organizational KPI's and they have to deliver value. That's the language that will be used at the decision-making level. But once the company's made the commitment or decision, then at an individual level its easy and permissible to use sustainability language." [Malcolm]

In this example, Malcolm illustrates not only the veneer of business case legitimacy used to cloak sustainability initiatives, but also how this business case logic is harnessed by activists on the inside to advance their own sustainability/ethical agendas.

Similarly, a common activist practice observed in the study was exploitation of the key instrumental business concerns around reputational risk and financial risk as a Trojan Horse to gain acceptance for personal normative concerns. For instance, Philippa plays on her company's concern for reputational risk and brand equity - in particular relating to the high sugar content in their food products - to shift their advertising content and campaigns away from targeting vulnerable children to their better-informed parents. As with the adoption of the Business Case, activist practices of playing to the core fears of their organization required 
resources - such as access to market data, personal credibility and inclusion in the right forums and processes to present their case.

We also observed activist practices of forming and influencing morality praxis internal and external to their organization. These morality praxis often took the form of inhouse peer-to-peer groups or industry communities, where peers, mentors and supervisors physically or virtually coalesced. For example, Paul formed an industry-level working group comprised of top-level managers from each of the major players the alcohol industry (commercial and government/non-profit) to address their role in the prevention of alcohol abuse amongst vulnerable populations. Acting more covertly, Melanie talks of how she artfully "weaves [sustainability] into the conversations, into the PowerPoints [presentations], into the spreadsheets" that she shares with her colleagues. Going further, some of our activist managers not only used praxis as an opportunity to weave their ethical concerns into the cultural fabric of their firm, they used these praxis as opportunities to trigger moral shocks (see definition below) in their peers and colleagues. For example, Philippa tells of how she covertly orchestrates environments and experiences as 'trigger events' that are designed to shock the moral sensibilities and unhinge the moral stabilities of her peers and superiors.

\section{INSERT TABLE 2}

These activist practices illustrate the importance of empowerment, moral shock and morality praxis as enabling contexts. We now expand on these important contexts of practice.

\section{Enabling Contexts of Activist Practice}

Understanding the cultural, organisational and symbolic context of practice is of crucial importance for practice theorists because actions cannot be reduced to an actor's adherence to 
rules and norms or rational choices (see Reckwitz, 2002, p 245). In this study, we are particularly interested in identifying the contextual parameters that make activist practices more or less likely to occur. Our analysis reveals three enabling conditions underpinning managerial responses of activism or abdication: (1) the sense of empowerment and perceived psychological safety to integrate specific issues into their business decisions; (2) a triggering event or sequence of events that cause the individual manager to connect their own managerial decisions and the actions of their firm to social and/or environmental harms that are contradictory to their own normative ethics; and (3) availability of a moral praxis that is determined by cutting-edge societal expectations and through which individuals can interact, coalesce, and link with these emerging moral sensibilities. We now present these conditions in detail.

\section{Empowerment, Agency and Psychological Safety}

We noted that to enact personal ethics in the workplace as activists on the inside required either empowerment so that "the values that underpin who I am, I have those with me" [Patrick] and "I personally believe so strongly in what I'm doing" [Anastasia], or, to have the agency to do so through covert tactics. Dimensions of this formal and informal agency included factors such as positional power, trust and credibility, knowledge of the business levers and informal decision-making networks, connections and personal relationships within the firm. In short, empowered managers feel psychologically safe to be themselves (Edmondson, 1999) because they are embedded in an organisational climate characterised by trust and respect for the manager. In scenarios where neither avenue was available, psychological safety was absent and informants faced untenable situations such as that articulated by Noelle when describing a situation of ethical conflict in her managerial experiences: 
"To be honest, [I was] scared that I would lose my job if I said something and then it backfired on me. It was more fear than anything else. I was scared that I would be without a job and I really like my job... You really are vulnerable". [Noelle]

These findings reveal the important role that activist business and team leaders play in enabling shifts towards sustainable and responsible business practices on a meso-business scale - the operations of their firm. We observed attempts by the business leaders and team managers in our study - from across the spectrum of small to large, and public to private firms - to internally influence their peers and subordinates using either empowerment or control approaches. First, attempts to create a climate of empowerment and psychological safety (Baer and Frese 2003; Frazier et al. 2016) within their teams were focused on providing subordinates with a sense of moral freedom, comfort and permission to be themselves and bring their own ethical norms and sustainability concerns into the workplace:

\footnotetext{
“As I've understood my purpose over time, there's a strong element that is around creating freedom for people. It started out with me wanting freedom for myself, not wanting to be over-controlled so that I could get on and do things. Over time it developed into creating freedom for other people - to open up the space [to] create the greatest freedom for people to make their own [ethical] decisions." [Paul]
}

In these scenarios, subordinates were encouraged to enact their moral-selves within the overarching ethical codes and moral ethos of the firm; yet, were also empowered to question and challenge this status quo in situations where the firm's broad moral ethos and codes contradicted their personal ethics. We found this approach of creating a climate of empowerment and safety to be reinforcing, with subordinate managers such as Melanie and Trevor, modelling similar practices of moral empowerment within their own teams and exercising their own ethical freedom in decision-making.

"So I feel like I'm able to be myself. I'm able to make the decisions that I think are the right decisions. And so, I [also] try to free up the people in my team to make decisions that are the right decisions for the way we should be going to market." [Melanie] 
"It's very important to me to be with an organisation that supports my intentions." [Trevor]

In contrast, we also observed activist managers and team leaders - including those who were the owners of private firms founded on environmental or social sustainability platforms - employing practices of control to shape workplace norms and cultures, and in doing so, encouraging their peers and employees to abdicate ethical responsibility and choice to the ethical norms of this powerful individual. For example, James describes the enculturation of new employees into the 'club' when they join a large multinational organization, while Jennifer also illustrates a similar form of cultural control to align with the normative ethics of the owner of her company - a small-medium private 'ethical' manufacturer:

"It's kind of a club, as soon as you become a [company employee]...you watch the new guys as they come on board, they have this drive that they must be doing something ethical, like taking time out to go and work on an ethical project. It's driven [from the top], it's culturally led...this [extends to] when they leave the office and go home to their family" [James]

"One of the things I'm constantly reminded of is that out there in the factory [are] 120 people that rely on us; [managing director] is forever putting that in my head: [Jennifer], you've got to remember that's our ethical responsibility." [Jennifer]

In this second scenario, peers and subordinates do not perceive the climate to be entirely safe for expressing personal views and preferences at the workplace. Indeed, James and Jennifer feel safer by abdicating ethical responsibility to the normative ethics of the powerful individual. We argue that in spaces that are not perceived as empowering and psychologically safe, the manager is more likely to use abdication as a coping tactic to rationalize away his or her inability to imbue decision making with personal preferences and normative ideals.

\section{Moral Shock}

We observed that the activists within our study had experienced an awakening (Carrington,

Neville, and Canniford 2015) or epiphany (Wright, Nyberg, and Grant 2012). This awakening 
occurred for informants when their internalised sense of normative ethics or sustainability concerns violently intersected with and breached the work-self boundary. The trigger events - or moral shocks (Jasper 1997) - leading to this awakening, which could occur either gradually or rapidly, were critical junctures in space and time that cause an irreversible transformation or shift (Carrington et. al., 2015; Wright et al., 2012). These events create a deeply felt shock when the individual realises that their own or their firm's business decisions may have contributed to social or environmental harms that they find personally abhorrent: "All of a sudden it was like, oh my God, this is shocking" [Paul]. This seismic shock catalyses an irreversible shift in their perspective; shattering illusions and fantasies that can never be reconstructed: "once you get out of the plausible deniability space you can't turn back" [Paul]. No longer could these individuals view their firm, their market offerings and the market itself as amoral spaces. A new affective space has been opened up in which a previously acceptable and comfortable form of professional life no longer feels right. One cannot go on living and working the same way. From this enlightened awareness and deep sense of concern, unmanageable conflict forces them to take action inside their organisation to attempt to re-align their business decisions with their normative ethical/sustainability concerns: "I was really dissatisfied, it didn't feel right...it felt unethical. I had to influence it." [Philippa].

In our study, it is through the experience of moral shock that our activist managers reimagine the market as morally charged and their perceptions of managerial decisions shift from being amoral to sites of moral dilemma. With this new conception of themselves as moral actors working in a moralised space, activists on the inside comprehend that in their managerial capacity they may have contributed to the social and ecological moral harms that they now find abhorrent. For instance, Paul suddenly recognized the social harm that his industry was causing to vulnerable sections of society and how deeply this impinged on his 
ethical sensibilities. This new self-awareness catalysed by an intense moral shock creates a deep sense of ontological insecurity (Giddens 1984) - a realisation that their moral vision and that of the firm are no longer aligned in particular situations - and motivation to re-calibrate their organization to align with this newly sourced moral code.

Importantly, for individuals to recognise a company's ethical transgression requires a willingness and capacity to see this transgression for what it is. Abdicators may see the exact same thing as activists, but unless abdicators are willing to recognise themselves as part of the problematic situation and as a fully engaged part of the company, they may not experience the situation as problematic or shocking. Thus, when we argue that an experience of deeply felt moral shock is a necessary initiation for the conventional manager to cross the threshold from abdication to sustainability and ethical activism, we also assert that this crossing over succeeds only when abdicators are willing to assume a minimum level of agency and to accept that there are no ontological guarantees (Giddens, 1984). This is evidenced in our conscious abdicators, who articulate experiences of moral shock, yet the intensity of their moral dissonance and concern remains low as does their sense of personal responsibility to enact change. For example, at the time of his interview Andreas had recently returned from working in a marginalized community where he experienced first-hand the damage that alcohol can do in such a community. This experience triggered a deep moral shock for Andreas, who manages an alcohol brand: "I now feel conflicted in that we continue to promote alcohol in [this community]. That conflicts with me". While Andreas observes business decisions that he feels uncomfortable with according to his new moral sensitivies, he is yet to "put my hand up and say I'm not comfortable with this", rather falling on reproduction practice and denial of responsibility to cope with this moral discomfort, suggesting that "I'm pretty well protected, more senior management make those decisions". In contrast, the unconscious abdicators in our study, such as Tiffany and David, do not 
articulate experiences of moral shock and discord. Rather, these informants describe a sense of ontological security and responsibility disassociation in the absence of connecting their business practices with their personal morality. Working under assumptions of the amorality of business, these unconscious abdicators sense that "you just go with it, go with the flow" (David).

\section{Morality Mediated Praxis}

Within the strategy-as-practice field, Jarzabkowski et al. (2007) stress the importance of praxis in enabling micro-micro level and micro-macro level interconnection and interaction, where praxis represents the dynamic interplay of "what is going on in society and what people are doing” (Sztompka, 1991, p 96). In our study, we discovered praxis where morality was a connective tissue mediating the personal worlds of the managers, the strategic world of the organization, and the outside world of society. Thus, morality was the nexus where two forms and layers of dynamic interaction occurred: (1) individual managers influencing other managers in morally charged sites of collaboration - such as the attempts of activist leaders in our study to catalyse grass-roots movements within their firms through various tactics of moral shock and empowerment; and (2) individual managers interacting with the shifting macro moral expectations of society (see also Weber and Waegner, 2017).

As noted previously, the formation and influencing of morality within this interactive praxis was a key activist practice to provoke ethical transformation within their businesses. These interactions engendered a two-way exchange at micro and macro levels. Activists were influenced by societal-level praxis that provoked shifts in their own moral compass and then sought to influence inward through micro-level peer-to-peer interactions. For example, Philippa tells of how she is "constantly pushing" in her peer-to-peer interactions for what she believes to be morally right, while James suggests that he has "been influenced massively" by 
the ethical concerns communicated within his business and through market research, because "you get on the bus and you get dragged along by it". Melanie describes the multi-directional interactions between herself, her organization (inward influence) and their consumers (outward influence) through morality mediated praxis: "consumers are always going to keep us in check. I feel like if I do something that doesn't align with their core value set, they're going to tell me. But we also have created core values that we're pushing out and absolutely we are trying to lead in that space." In contrast, the abdicator managers in our study experienced one-way interactions - being influenced through morality mediated praxis, but not attempting to influence.

Morality mediated praxis were evidenced through the emergence of a new generation of business leaders that a number of our participants called the third wave or third generation. While the activists on the inside in our study generally identified themselves as loners in their organisation, some informants also self-identified as part of a broader "third generation" [Paul] of responsible business managers and leaders. Consider, for example, the narratives of Patrick and Paul of this new wave of business management, and their own place within it.

"I now see a third change, there's been a shift. When I started, it was the young marketers, like myself, who were asking the questions [about sustainability] and sourcing the suppliers. It wasn't coming from above. As we [have] moved into more senior roles that ethos has come with us - around we need to do something about it; and now we are able to actually do something about it. That is the catalyst for change... In this capacity, I can voice my concerns, I can influence and I can gather the facts to support a particular point of view." [Patrick]

"I think a generation of business leaders has started to emerge and started to pick the issues and work on them but not yet - it hasn't yet got full voice... When I started out, the whole notion of triple bottom line came out, the generation ahead didn't quite get it, but they knew that they had to talk the talk. I took a view at that stage that I don't care that they're not doing anything because at least they're using the language, and then the next generation of leaders that follow them will have started from that position and then they'll start to bring meaning to it. Then the next generation after that - the third generation - will start to bring the next level of meaning to it. I do see a group of [leaders] coming through, who are thoughtful about the growth of the business, thoughtful about the growth of the economy and what role they have to play, but that's not the norm yet." [Paul] 
In this conception, previous generations of business leaders - such as the baby boomers otherwise identified as "generation greed" (Paul) - are moving out of leadership roles, making space for a new generation of activist business leaders to now have the power to bring their moral self to bare in business decisions and to significantly "change the model" from the inside. This new generation of activist managers senses that it is bringing its their own moral sensibilities to business practice, and in doing so, is both tapping into shifting moral expectations of business and are coalescing around these moral expectations through societally-driven praxis. Identity struggles, strategies of concealment and creating underhanded acts of subversion that do not threaten one's position in the system are perceived as irrelevant detours for the job that needs to be done. This generation of managers focuses on action as the source of change.

\section{INSERT TABLE 3}

\section{DISCUSSION}

Ethical business and corporate social responsibility are facing criticisms that cut to the core of their ability to enact positive change as difficult questions arise for business leaders and management scholars about the role of business in the creation of some of the biggest challenges of our time, such as environmental degradation and intensifying economic inequality. The question facing the field of business ethics and CSR is whether businesses can be part of the solution to the very same challenges to which conventional business practices have contributed. In this paper, we extend this discussion by focusing on the everyday practices of activist managers as social intrapreneurs. We contend that everyday practices inside organizations must change if businesses are to become drivers of a socially 
and environmentally sustainable, and equitable, form of capitalism. Thus, we pursue a research agenda that investigates what kind of practices activists and social intrapreneurs engage in to influence organizational social and environmental practices, and the conditions that enable managers to feel encouraged and compelled to engage in such activist practices. This analysis enables us to theorize the potential impact of organizationally diffused and often uncoordinated micro-practices of managers on overall ethical practices and responsible behaviour of the organization. Thus, we contribute in a modest way to the larger conversation about the possibility of business to affect social, economic and environmental concerns in an ethical and responsible manner.

As such, we contribute to the literature on social intrepreneurs, which has thus far focused upon their identity-based experience of conflicting values with their firm (e.g. Brickson, 2000, 2013; Hemingway, 2005; Meyerson and Scully, 1995; Wright, Nyberg, and Grant, 2012) and their strategic efforts at social change within their firm (e.g., Briscoe and Gupta, 2016; Courpasson, Dany \& Clegg, 2012; Meyerson and Scully, 1995), especially through the process of 'issue selling' (e.g. Alt and Craig, 2016; Andersson and Bateman, 2000; Heinze and Weber, 2015; Sonenshein, 2016; Wickert and de Bakker, 2016). Our findings paint a more comprehensive picture of the conditions that enable value conflict to manifest through activism rather than abdication. We also view social intrapreneurs' activism through a strategy-as-practice lens, which shows what social intrapreneurship looks like at the everyday level of practice (Jarzabkowski, 2004).

We draw on extensive interview data to empirically develop a model - Figure 3 - that integrates the study findings to show how activists and social intrapreneurs find various ways to put their values into practice. We also find that organizational context matters when it comes to enabling activist practice. We suggest that our findings are encouraging for management scholars who argue that businesses can be a positive force for a more socially 
just, economically fair and environmentally sustainable capitalism. We now discuss this dynamic model in detail (see Figure 3).

\section{INSERT FIGURE 3}

\section{Making the Activist: Enabling conditions and (c)overt tactics}

Our model presents a useful representation that dichotomizes managerial practices into 'reproducing the status quo' on the one hand and (aspiring to be) 'transforming the status quo' on the other. We call these two practice-orientations abdication and activism, respectively. In our study, we find informants who position themselves at the polar ends of these two orientations - abdicators (conscious, unconscious) and permanent activists, as well as those who shift between the two practice-orientations - hybrid activists. The hybrid activists in particular display the dynamic shifts in and out of moral decision making predicted by Weitzner and Deutsch (2015), while abdicators and activists displayed entrenched positions with little or no cross-over.

Those informants who take an abdication orientation are generally willing to condone the dominant logic of capitalist organizations, even though the conscious abdicators may experience moral conflict in doing so. Abdicators cope with the conflict between personal and organization/system-driven values by distancing themselves from the responsibility of taking action. This responsibility is outsourced to other stakeholders, such as customers, senior managers or governments, which allows the abdicator to maintain a sense of professional identity even as she makes decisions and takes actions that are personally ethically and morally disagreeable. In contrast, our informants who took an activism orientation were often unwilling to compromise personal values for organizational expedience. These activists report engaging in covert and overt tactics to bring different sets 
of practices into current organizational processes. Importantly, we find in our data evidence that context matters when it comes to "making" activist managers in an organization. We identify three distinct contexts, or what we call 'enabling conditions': empowerment and psychological safety, moral shock and morality praxis, and we argue that when these conditions are present in some form, social intrapreneurs are more likely to pursue practices that challenge the dominant narrative of the organization.

Our study points to the important role that activist business leaders play in providing an empowering and psychologically safe climate, and to actively drive cultural shifts towards sustainable and responsible business practices. Indeed, business leaders can even orchestrate moral shocks to trigger a sense of urgency and moral awareness in others within their firm. Our analysis strongly suggests that the presence of top-down activists on the inside - such as Paul - can encourage bottom-up activism in their organisation that reinforces shifting moral sensibilities and accelerates the speed of corporate and industry transformation. Paul offers to his co-workers both a source for continuous moral jolting and a sense of empowerment and safety. Figures like Paul therefore become important catalysts for more socially and morally engaged business practice. This finding contributes to our understanding of the situational factors that play a contingent role in the triggering of ethical and CSR related decisionmaking at an individual level (e.g. Kaptein, 2011; Trevino, Weaver, and Reynolds, 2006). More generally, our research suggests that enabling conditions such as moral shock and a climate of empowerment and safety play a key role in fostering individual practices that have, in principle and on aggregate, the capacity to make businesses more responsible from the inside, one covert or overt move at a time.

\section{The Power of Practice}


A practice theoretical approach aims to create knowledge about the world through capturing and interpreting the practices and actions of the world's inhabitants, and by taking into consideration the context in which these actions and practices take place (Reckwitz 2002; Warde 2005). This study goes inside businesses to understand the world of social intrapreneurs by looking at what they do and under what conditions they do it, rather than ask: who are they? Thus, CSR and ethical business becomes a matter of detecting concrete material actions rather than abstract objects of strategic, economic, or political relevance. Practice theory comes about as the product of capturing and integrating the everyday (de Certeau, 1984) and a strategy-as-practice approach prompts us to pay specific methodological attention to the forms of justification that managers attach to managerial practice (see also Jarzabkowski, 2004).

Studying ethical and moral activism at the level of everyday material practice is challenging because organizational and managerial practice is often purposefully hidden from public or scholarly view. A strategy-as-practice approach is further complicated by the fact that activist activities are happening in many different places and at many different decisionmaking levels in organizations and are not guided by an integrative framework, company policy or functional unit. Activist practice, as we learn from our informants, is not centrally organized, coordinated and strategically structured.

From this vantage point, our study begins to add a practice approach to the responsible business and ethics literature on organizational change that is largely dominated by concerns about identity construction and strategic action (e.g. Iivonen and Moisander, 2015; Carroll and Shabana, 2010; Sharma, 2000; Phillips, 2012; Meyerson and Scully, 1995; Wright et al., 2015) and the dynamic attitudes of managers towards moral claims (Weitzner and Deutsch, 2015). We contend, however, that if business wants to be a force for positive change it must alter its practices to support environmental sustainability, social justice and 
economic equity. Therefore, notwithstanding theoretical and methodological challenges of practice research, the insights into the emergence of activists and the tactics of influencing the organization through practice that are revealed through our study offer an important understanding of how and where transformation of business practices could originate.

Our most ambitious goal is to explore whether micro-actions and -practices that are not organized through clearly recognizable processes (e.g. Alt and Craig, 2016), generated by explicit strategic frameworks (e.g. Courpasson, Dany and Clegg, 2012) or prescribed by a central ‘champion’ (e.g., Andersson and Bateman, 2000) can make business more responsible. To establish a connection between the diffused practice of activist managers and overall changes of organizational practices is challenging. We theorize such a connection, however, by integrating our findings with previous research. Several of our informants report how their actions (covert and overt) do affect functional, departmental, organizational, and even industry agendas, ideas and ultimately practices. As Ansari and Phillips (2011) put it, micro-practices have the capacity to "cumulatively bubble up" and facilitate change of established business practices, and to transform workplaces and management decisions (Courpasson et al, 2012). To affect cumulative transformation, these micro-practices are neither atomized nor random. Praxis can present sites of interaction between individual and societal moralities (Sztompka, 1991), that enable individual managers to plumb societal moral expectations through their interactions. These societal macro-level moral expectations can be absorbed and enacted in the daily practice of individual managers. Thus, we build on earlier work by Weber and Waegner (2017) and Weitzner and Deutsch (2015) to theorize how the contextual influences of powerful stakeholders and society at large can be reflected in micro-level acts of managers, and that this individual practice can be cumulatively aggregated when underpinned by common societal moralities absorbed through praxis interaction. Thus, we theorize the possibility for significant transformation and reformation of 
business practices and logics through the cumulative actions of activist managers who are 'on the inside'. This system level business transformation is dialogically linked to the changing moral sensibilities of society and mediated through the transformative practice of activist managers - such as Patrick, Susan and Anastasia. In summary, the changing moral expectations of society are absorbed by activist managers through morality-mediated interactions at the focal points formed at praxis, who in turn enact transformative practice within their organizations that aligns with these shifting moral expectations. We theorize that these individual acts of transformative practice could cumulatively 'bubble up' to affect meso- and macro-level business reformation, and this reformation aligns with shifting societal moral sensibilities (see Figure 3).

A strategy-as-practice approach such as ours, takes the seemingly small and often overlooked cues of the everyday to paint a more accurate picture of how everyday managerial practice might impact social, economic, and environmental sustainability at an aggregate level. Without this deliberate observation of the everyday taken in this study, we suggest that the field of CSR and ethical business studies may underestimate the potential of the uncoordinated actions of individual managers, as these practices are hard to detect, measure and put into a cohesive analytical framework. Thus, we contend that there is a considerable need for scholarship in CSR that pays careful attention to the seemingly insignificant and understated everyday practices of internal activist managers, or risk underestimating the transformative power latently present in organizations.

\section{CONCLUSION}

Arguably the central question for management scholars interested in "responsible business" (Crane and Matten 2009) is whether businesses and corporations can be enablers or disablers 
of a more environmentally sustainable and socially just world. On this question, scholars largely fall into two camps. One camp suggests that businesses, when run properly, are critical for the creation of a more sustainable ecosystem and a fairer economic system (Barton 2011; Crocker and Linden 1998; Porter and Kramer 2011). Another camp is much less sanguine about the ability of businesses to solve urgent social, ethical and environmental challenges of our time. These scholars often suggest that business is responsible for the current predicament and to expect businesses to save us from the intensifying ecological, economic, and social crises is therefore misguided (Banerjee 2008, 2011; Blowfield 2005; Bondy et al. 2012; Doane 2005; Fleming and Jones 2012; Iivonen and Moisander 2015; Szmigin and Rutherford 2013).

In opening the 'black box' of the firm and looking inside at the everyday practice of managers, we reconsider and reframe the role that these individuals can play in the transformation of business to a more ethical, responsible and value-based practice. Importantly, our theoretical model shows the mechanisms and conditions that work to enable or prevent this transformation. Our study suggests that under the right conditions managers are able to affect firm conduct from the inside. Our interviews show that tactics that may appear to sceptics of responsible business as, at best, pointless acts of agitation (Fleming and Sewell 2002)and at worst mere compliance to the dominant model (Klikauer 2015) have the potential to change practice "on the ground". We acknowledge that the dice are loaded against the activist manager. Our data does show that managers are prone to finding ways to abdicate responsibility to transform capitalism one act at a time. Managers may well be more likely to reproduce the practices already in place than challenge and subvert them. Nonetheless we also find evidence for the activist manager who does affect change from the inside. Critical scholars who paint a bleak picture of the possibility of business ever being anything but rapacious, profit maximisers, do caveat that there are exceptions (e.g., Fleming 
and Jones, 2012). Our data suggests that when managers are given the chance to experience current practices as morally suspect, if not outright wrong, and feel empowered and psychologically safe to do something about it, they will in fact do so. Thus, we submit that irresponsible and unethical practice is not immanent to business, and that we should refrain from abdicating managers from the responsibility to find ways to make capitalism better.

Rather than business organisations being viewed as monolithic, singular and selfinterested agents, they are replete with heterogeneous ethical actors with the potential to enact change (Felin, et al., 2015; Clegg and Higgins, 1987; Weitzner and Deutsch, 2015). We see the activist managers in our study as a vanguard in the rearticulation and reformation of a constraining business logic single-mindedly wedded to the profit principle. We do not know if there are enough of these fully engaged managers willing to transform business practice at a rate and a speed needed to achieve the Sustainable Development Goals or make global capitalism equitable. Certainly, it is too little too late to save us from all but the worst effects of climate change (IMF, 2015). Nevertheless, our investigation of managerial practice at the micro-level provides evidence of the possibility of change from within the system.

The deep tension, as Fleming and Jones (2012) remind us, between what many of our managers aspire themselves and their organizations to be (ethical, sustainable, just, etc.) and the twin demand of maximising profit and shareholder value may never disappear. Yet, we argue that material acts of activism and moral transformation that on the surface may appear as atomized and futile undertakings of idealist individuals could add up to a collective groundswell toward a reformed capitalism where profitability and growth are achieved ethically and sustainably. Thus, when asking the larger question: what role can individual managers play in the necessary transformation of current business practice and the economic system, we find that under the right circumstances managers are able to find ways to make responsible business happen. Our informants demonstrate that this possible future is already 
contained in many organisations - individual managers going about their daily routines have the potential, and thus the responsibility, to drive this change. 


\section{REFERENCES}

Acquier, A., T. Daudigeos, and B. Valiorgue (2011), "Corporate Social Responsibility as an Organizational and Managerial Challenge: The Forgotten Legacy of the Corporate Social Responsiveness Movement," M@n@gement, 14 (4), 222-50.

Aguinis, H. and A. Glavas (2012), "What We Know and Don't Know About Corporate Social Responsibility a Review and Research Agenda," Journal of management, 38 (4), 932-68.

Allen, S., J. Marshall, and M. Easterby-Smith (2015), "Living with Contradictions the Dynamics of Senior Managers' Identity Tensions in Relation to Sustainability," Organization \& Environment, 1086026615575048.

Alt, E. and J. Craig (2016), "Selling Issues with Solutions: Igniting Social Intrapreneurship in for-Profit Organizations," Journal of Management Studies, 53 (5), 794-820.

Bhattacharjee, A., J.Z. Berman, and A. Reed II (2013), "Tip of the Hat, Wag of the Finger: How Moral Decoupling Enables Consumers to Admire and Admonish," Journal of Consumer Research (6), 1167.

Edmondson, A. (1999), "Psychological Safety and Learning Behavior in Work Teams," Administrative Science Quarterly (2), 350.

Andersson, L.M. and T.S. Bateman (1997), "Cynicism in the Workplace: Some Causes and Effects," Journal of organizational behavior, 449-69.

Ansari, S. and N. Phillips (2011), "Text Me! New Consumer Practices and Change in Organizational Fields," Organization Science, 22 (6), 1579-99.

Baer, M. and M.Frese (2003), "Innovation Is Not Enough: Climates for Initiative and Psychological Safety, Process Innovations, and Firm Performance," Journal of organizational behavior, 24 (1), 45-68. 
Banerjee, S.B. (2008), "Corporate Social Responsibility: The Good, the Bad and the Ugly," Critical sociology, 34 (1), 51-79.

--- (2011), "Embedding Sustainability across the Organization: A Critical Perspective," Academy of Management Learning \& Education, 10 (4), 719-31.

Bansal, P. (2003), "From Issues to Actions: The Importance of Individual Concerns and Organizational Values in Responding to Natural Environmental Issues," Organization Science, 14 (5), 510-27.

Barton, D. (2011), "Capitalism for the Long Term," Harvard Business Review, 89 (3), 84-91. Blowfield, M. (2005), "Corporate Social Responsibility-the Failing Discipline and Why It Matters for International Relations," International Relations, 19 (2), 173-91.

Bondy, K., J.Moon, and D.Matten (2012), "An Institution of Corporate Social Responsibility (Csr) in Multi-National Corporations (Mncs): Form and Implications," Journal of Business Ethics, 111 (2), 281-99.

Bourdieu, P. (1997). Outline of a theory of practice. Cambridge University Press

Brickson, S. (2000), "The Impact of Identity Orientation on Individual and Organizational Outcomes in Demographically Diverse Settings," Academy of management Review, $25(1), 82-101$.

Brickson, S. (2013), "Athletes, Best Friends, and Social Activists: An Integrative Model Accounting for the Role of Identity in Organizational Identification," Organization Science, 24 (1), 226-45.

Briscoe, F. and A.Gupta (2016), "Social Activism in and around Organizations," Academy of Management Annals, 10 (1), 671-727.

Carrington, M.J. and B.Neville (2016), "Marketers Are Consumers Too: Integrating Consumer-Self in Potential Value Creation," European Journal of Marketing (5-6). 
Carrington, M.J., B.Neville, and R.Canniford (2015), "Unmanageable Multiplicity:

Consumer Transformation Towards Moral Self Coherence," European Journal of Marketing, 49 (7/8), 1300-25.

Carrington, M.J., D.Zwick, and B.Neville (2016), "The Ideology of the Ethical Consumption Gap," Marketing Theory, 16 (1), 21-38.

Carroll, A.B. and K.M. Shabana (2010), "The Business Case for Corporate Social Responsibility: A Review of Concepts, Research and Practice," International Journal of Management Reviews, 12 (1), 85-105.

Clegg, S.R. and W.Higgins (1987), "Against the Current: Organizational Sociology and Socialism," Organization Studies, 8 (3), 201-21.

Corbin, J.M. and A.L.Strauss (2008), Basics of Qualitative Research : Techniques and Procedures for Developing Grounded Theory: Los Angeles : SAGE Publications, c2008. 3rd ed.

Corley, K.G. and D.A. Gioia (2004), "Identity Ambiguity and Change in the Wake of a Corporate Spin-Off," Administrative Science Quarterly, 49 (2), 173-208.

Courpasson, D., F.Dany, and S.Clegg (2012), "Resisters at Work: Generating Productive Resistance in the Workplace," Organization Science, 23 (3), 801-19.

Cragg, W. (1997), "Teaching Business Ethics: The Role of Ethics in Business and in Business Education," Journal of Business Ethics, 16 (3), 231-45.

Crane, A. and D. Matten (2009), "How to Integrate Responsible Business," http://craneandmatten.blogspot.ca/2009/10/how-to-integrate-responsiblebusiness.html.

Crocker, D. A. and T. Linden (1998), Ethics of Consumption: The Good Life, Justice, and Global Stewardship: Rowman \& Littlefield. 
Doane, D. (2005), "Beyond Corporate Social Responsibility: Minnows, Mammoths and Markets," Futures, 37 (2), 215-29.

Donaldson, T. and L.E. Preston (1995), "The Stakeholder Theory of the Corporation: Concepts, Evidence, and Implications," Academy of management Review, 20 (1), 6591.

Dopfer, Foster and Potts (2014). "Micro-Meso-Macro," Journal of Evolutionary Economics, 14(3):263-279.

Felin, T., N.J. Foss, and R.E. Ployhart (2015), "The Microfoundations Movement in Strategy and Organization Theory," The Academy of Management Annals, 9 (1), 575-632.

Fleming, P. and M. Jones (2012), The End of Corporate Social Responsibility : Crisis \& Critique: Sage.

Fleming, P. and G. Sewell (2002), "Looking for the Good Soldier, Švejk Alternative Modalities of Resistance in the Contemporary Workplace," Sociology, 36 (4), 857-73.

Frazier, M. L., S. Fainshmidt, R. L. Klinger, A. Pezeshkan, and V. Vracheva (2016), "Psychological Safety: A Meta-Analytic Review and Extension," Personnel Psychology.

Geppert, M. and C. Dörrenbächer (2014), "Politics and Power within Multinational Corporations: Mainstream Studies, Emerging Critical Approaches and Suggestions for Future Research," International Journal of Management Reviews, 16 (2), 226-44.

Giddens, A. (1984), The Constitution of Society : Outline of the Theory of Structuration: Berkeley : University of California Press, 1984.

Gioia, D. A., K. G. Corley, and A. L. Hamilton (2013), "Seeking Qualitative Rigor in Inductive Research Notes on the Gioia Methodology," Organizational Research Methods, 16 (1), 15-31. 
Goffman, E. (1959), The Presentation of Self in Everyday Life: Garden City, N.Y., Doubleday, 1959.

Gond, J.P., S. Grubnic, C. Herzig, and J. Moon (2012), "Configuring Management Control Systems: Theorizing the Integration of Strategy and Sustainability," Management Accounting Research, 23 (3), 205-23.

Hammersley, M. and P. Atkinson (2007), Ethnography : Principles in Practice: London ; New York : Routledge, 2007. 3rd ed.

Harrison, J. S., D. A. Bosse, and R. A. Phillips (2010), "Managing for Stakeholders, Stakeholder Utility Functions, and Competitive Advantage," Strategic Management Journal, 31 (1), 58-74.

Hatch, M. J., and Schultz, M. (2017), "Toward a Theory of Using History Authentically: Historicizing in the Carlsberg Group", Administrative Science Quarterly, 62(4), 657697

Heinze, K. L. and K. Weber (2016), "Toward Organizational Pluralism: Institutional Intrapreneurship in Integrative Medicine," Organization Science (1), 157.

Hemingway, C. A. (2005), "Personal Values as a Catalyst for Corporate Social Entrepreneurship," Journal of Business Ethics, 60 (3), 233-49.

Iivonen, K. and J. Moisander (2015), "Rhetorical Construction of Narcissistic CSR Orientation," Journal of Business Ethics, 131 (3), 649-64.

IMF (2015), "The Managing Director's Statement on the Role of the Fund in Addressing Climate Change," http://www.imf.org/external/np/pp/eng/2015/112515.pdf: International Monetary Fund.

Jarzabkowski, P. (2004), "Strategy as Practice: Recursiveness, Adaptation, and Practices-inUse," Organization Studies, 25 (4), 529-60. 
Jarzabkowski, P. (2008) Strategy as Practice : An Activity Based Approach, SAGE Publications.

Jarzabkowski, P., J. Balogun, and D. Seidl (2007), "Strategizing: The Challenges of a Practice Perspective," Human Relations, 60 (1), 5-27.

Jasper, J. M. (1997), The Art of Moral Protest : Culture, Biography, and Creativity in Social Movements: Chicago ; London : University of Chicago Press, 1997.

Johnson, G., Melin, L. and Whittington, R. (2003) 'Micro strategy and strategizing: Towards an activity-based view?', Journal of Management Studies, 40, 1: 3- 22.

Jones, T. M, W. Felps, and G. A. Bigley (2007), "Ethical Theory and Stakeholder-Related Decisions: The Role of Stakeholder Culture," Academy of management Review, 32 (1), 137-55.

Klikauer, T. (2015), Hegel's Moral Corporation: Palgrave Macmillan.

Leonardi, P. M. and S. R. Barley (2008), "Materiality and Change: Challenges to Building Better Theory About Technology and Organizing," Information and Organization, 18, 159-76.

Maak, T., N. M. Pless, and C. Voegtlin (2016), "Business Statesman or Shareholder Advocate? Ceo Responsible Leadership Styles and the Micro-Foundations of Political CSR," Journal of Management Studies, 53 (3), 463-93.

Marcus, G. E. (1995), "Ethnography in/of the World System: The Emergence of Multi-Sited Ethnography," Annual review of anthropology, 95-117.

McCracken, G. D. (1988), The Long Interview: Newbury Park, Calif. : Sage Publications, c1988.

Meyerson, D. E. and M. A. Scully (1995), "Crossroads Tempered Radicalism and the Politics of Ambivalence and Change," Organization Science, 6 (5), 585-600. 
Miles, M. B. and A. M. Huberman (2002), The Qualitative Researcher's Companion: Thousand Oaks ; London : Sage Publications, c2002.

Orlikowski, W. J (2002), "Knowing in Practice: Enacting a Collective Capability in Distributed Organizing," Organization Science, 13 (3), 249-73.

Orlitzky, M., F. L. Schmidt, and S. L. Rynes (2003), "Corporate Social and Financial Performance: A Meta-Analysis," Organization Studies, 24 (3), 403-41.

Piketty, T. (2014), Capital in the Twenty-First Century: Harvard University Press.

Porter, M. E. and M. R. Kramer (2011), "The Big Idea: Creating Shared Value," Harvard Business Review, 89 (1), 2.

Reckwitz, A. (2002), "Toward a Theory of Social Practices a Development in Culturalist Theorizing," European journal of social theory, 5 (2), 243-63.

Scherer, A. G., A. Rasche, G. Palazzo, and A. Spicer (2016), "Managing for Political Corporate Social Responsibility: New Challenges and Directions for Pcsr 2.0," Journal of Management Studies, 53 (3), 273-98.

Sharma, S. (2000), "Managerial Interpretations and Organizational Context as Predictors of Corporate Choice of Environmental Strategy," Academy of Management Journal, 43 (4), 681-97.

Sonenshein, S. (2016), "How Corporations Overcome Issue Illegitimacy and Issue Equivocality to Address Social Welfare: The Role of the Social Change Agent," Academy of management Review (2), 346.

Szmigin, I. and R. Rutherford (2013), "Shared Value and the Impartial Spectator Test," Journal of Business Ethics, 114 (1), 171-82.

Sztompka, P. (1991), Society in Action: The Theory of Social Becoming: University of Chicago Press. 
Tello-Rozas, S., M. Pozzebon, and C. Mailhot (2015), "Uncovering Micro-Practices and Pathways of Engagement That Scale up Social-Driven Collaborations: A Practice View of Power," Journal of Management Studies, 52 (8), 1064-96.

Thompson, C. J. and M. Troester (2002), "Consumer Value Systems in the Age of Postmodern Fragmentation: The Case of the Natural Health Microculture," Journal of Consumer Research, 28 (4), 550-71.

UNFCCC (2015), United Nations Framework Convention on Climate Change, https://unfccc.int/resource/docs/2015/cop21/eng/I09r01.pdf

Warde, A. (2005), "Consumption and Theories of Practice," Journal of Consumer Culture, 5 (2), 131-53.

Weber, K. and D. Waeger (2017), "Organizations as Polities: An Open Systems Perspective," Academy of Management Annals, annals. 2015.0152.

Weitzner, D. and Y. Deutsch (2015), "Understanding Motivation and Social Influence in Stakeholder Prioritization," Organization Studies, 36 (10), 1337-60.

Wickert, C. and F. de Bakker (2016), "Pitching for Social Change: Towards a Relational Approach to Selling and Buying Social Issues," Academy of Management Discoveries, amd. 2015.0009.

Williams, P. (2002), "The Competent Boundary Spanner," Public Administration, 80 (1), 103.

Wright, C. and D. Nyberg (2015), Climate Change, Capitalism, and Corporations: Cambridge University Press.

Wright, C., D. Nyberg, and D. Grant (2012), "'Hippies on the Third Floor': Climate Change, Narrative Identity and the Micro-Politics of Corporate Environmentalism," Organization Studies (11), 1451. 
TABLE 1. Research Participants

\begin{tabular}{|c|c|c|c|c|c|}
\hline Pseudonym & Position/Function & Organization Type & Industry & $\begin{array}{l}\text { Perceived Congruence } \\
\text { Work \& Self }\end{array}$ & $\begin{array}{l}\text { Perceived Org. Culture } \\
\text { Empowerment / Control }\end{array}$ \\
\hline Anastasia & $\begin{array}{l}\text { Marketing \& Product } \\
\text { Manager }\end{array}$ & $\begin{array}{l}\text { Manufacturer and Retailer ('Ethical' focus) } \\
\text { - National Distribution } \\
\text { - Niche / local market }\end{array}$ & Confectionary & High & Empowerment \\
\hline Andreas & $\begin{array}{l}\text { Customer Insight / Brand } \\
\text { Management }\end{array}$ & $\begin{array}{l}\text { Manufacturer } \\
\text { - National distribution } \\
\text { - Market Leader }\end{array}$ & Beverages & Low & Control \\
\hline Brandon & Supply Chain Manager & $\begin{array}{l}\text { Multinational Manufacturer } \\
\text { - Market leader or strong competitor }\end{array}$ & Alcoholic Beverage & $\begin{array}{l}\text { Relatively high } \\
\text { (informant unreflexive) }\end{array}$ & Control \\
\hline Colin & National Sales Manager & $\begin{array}{l}\text { Multinational Manufacturer } \\
\text { - Market leader or strong competitor }\end{array}$ & $\begin{array}{l}\text { Foodservice } \\
\text { Catering/Grocery }\end{array}$ & $\begin{array}{l}\text { Variable - dependent on } \\
\text { specific issues }\end{array}$ & Control \\
\hline David & National Sales Manager & $\begin{array}{l}\text { Multinational Manufacturer } \\
\text { - Market leader or strong competitor }\end{array}$ & Agricultural/FMCG & $\begin{array}{l}\text { Relatively high } \\
\text { (informant unreflexive) }\end{array}$ & Control \\
\hline Deborah & Marketing Consultant & $\begin{array}{l}\text { Market Research and Brand Management } \\
\text { Consultants } \\
\text { - Multinational } \\
\text { - Market leader in sector }\end{array}$ & $\begin{array}{l}\text { Cross-industry, } \\
\text { strong presence in } \\
\text { FMCG }\end{array}$ & $\begin{array}{l}\text { Relatively high } \\
\text { (informant unreflexive) }\end{array}$ & Empowerment \\
\hline James & Head of Marketing & $\begin{array}{l}\text { Manufacturer } \\
\text { - National distribution } \\
\text { - Market Leader } \\
\end{array}$ & Food - Catering & $\begin{array}{l}\text { Variable - dependent on } \\
\text { specific issues }\end{array}$ & Control \\
\hline Jennifer & $\begin{array}{l}\text { Sales and Marketing } \\
\text { Director }\end{array}$ & $\begin{array}{l}\text { Manufacturer ('Ethical' focus) } \\
\text { - National distribution } \\
\text { - Market leader or strong competitor }\end{array}$ & $\begin{array}{l}\text { Home and Personal } \\
\text { Care Products }\end{array}$ & High & Control \\
\hline Jerome & Private Label Manager & $\begin{array}{l}\text { Major Retail Chain } \\
\text { - Market Leader }\end{array}$ & Grocery & $\begin{array}{l}\text { Variable - dependent on } \\
\text { specific issues }\end{array}$ & Control \\
\hline Juliette & Marketing Manager & $\begin{array}{l}\text { Marketing and Advertising Agency } \\
\text { - Multinational } \\
\text { - Market Leader in Sector }\end{array}$ & Service Industry & $\begin{array}{l}\text { Relatively high } \\
\text { (informant unreflexive) }\end{array}$ & Control \\
\hline Malcolm & Relationship Manager & NGO & FMCG Focus & High & Empowerment \\
\hline Melanie & Marketing Manager & $\begin{array}{l}\text { Manufacturer and Retailer } \\
\text { - Multinational } \\
\text { - Market Leader in Sector }\end{array}$ & $\begin{array}{l}\text { Food and } \\
\text { Beverages }\end{array}$ & High & Empowerment \\
\hline
\end{tabular}




\begin{tabular}{|c|c|c|c|c|c|}
\hline Michael & Managing Director/ Founder & $\begin{array}{l}\text { Wholesaler ('Ethical' focus) } \\
\text { - National distribution } \\
\text { - Strong presence in high-end market }\end{array}$ & $\begin{array}{l}\text { Paper goods and } \\
\text { Stationary }\end{array}$ & High & Empowerment \\
\hline Nigel & Head of Marketing & $\begin{array}{l}\text { Manufacturer } \\
\text { - Market Leader } \\
\text { - International Distribution }\end{array}$ & Agricultural/FMCG & $\begin{array}{l}\text { Variable - dependent on } \\
\text { specific issues }\end{array}$ & Control \\
\hline Noelle & Head of Marketing & $\begin{array}{l}\text { Multinational Manufacturer } \\
\text { - Market leader or strong competitor }\end{array}$ & Hardware / DIY & $\begin{array}{l}\text { Variable - dependent on } \\
\text { specific issues }\end{array}$ & Control \\
\hline Patrick & Senior Brand Manager & $\begin{array}{l}\text { Multinational Manufacturer } \\
\text { - Market leader or strong competitor }\end{array}$ & FMCG & High & Empowerment \\
\hline Paul & CEO & $\begin{array}{l}\text { Multinational Manufacturers } \\
\text { - Market leader or strong competitor }\end{array}$ & Various & High & Empowerment \\
\hline Philippa & Senior Brand Manager & $\begin{array}{l}\text { Multinational Manufacturer } \\
\text { - Market leader or strong competitor }\end{array}$ & FMCG & High & Empowerment \\
\hline Randall & Sustainability Director & $\begin{array}{l}\text { Manufacturer } \\
\text { - National Distribution } \\
\text { - Market Leader }\end{array}$ & Automotive & $\begin{array}{l}\text { Relatively high } \\
\text { (informant unreflexive) }\end{array}$ & Control \\
\hline Rhonda & $\begin{array}{l}\text { CEO / Non-Exec Board } \\
\text { Director }\end{array}$ & $\begin{array}{l}\text { Multinational Manufacturers \& Retailers } \\
\text { - Market leader or strong competitor }\end{array}$ & Various & High & Empowerment \\
\hline Rebecca & Marketing Manager & $\begin{array}{l}\text { Manufacturer ('Ethical' focus) } \\
\text { - National distribution } \\
\text { - Market leader or strong competitor }\end{array}$ & $\begin{array}{l}\text { Home and Personal } \\
\text { Care Products }\end{array}$ & High & Control \\
\hline Scott & Retail Category Buyer & $\begin{array}{l}\text { Major Retail Chain } \\
\text { - Market Leader }\end{array}$ & Grocery & $\begin{array}{l}\text { Variable - dependent on } \\
\text { specific issues }\end{array}$ & Control \\
\hline Seamus & Marketing Manager & $\begin{array}{l}\text { Manufacturer and Retailer ('Ethical' focus) } \\
\text { - National Distribution } \\
\text { - Niche / local market }\end{array}$ & $\begin{array}{l}\text { Fashion } \\
\text { Accessories (made } \\
\text { from recycled } \\
\text { materials) }\end{array}$ & High & Empowerment \\
\hline Susan & $\begin{array}{l}\text { Quality Control and } \\
\text { Compliance }\end{array}$ & $\begin{array}{l}\text { Major Retail Chain } \\
\text { - Market Leader } \\
\end{array}$ & Grocery & $\begin{array}{l}\text { Variable - dependent on } \\
\text { specific issues }\end{array}$ & Control \\
\hline Tiffany & Brand Manager & $\begin{array}{l}\text { Multinational Manufacturer } \\
\text { - Market leader or strong competitor } \\
\text { - International Distribution }\end{array}$ & $\begin{array}{l}\text { Personal Care } \\
\text { Products }\end{array}$ & $\begin{array}{l}\text { Relatively high } \\
\text { (informant unreflexive) }\end{array}$ & Control \\
\hline Trevor & Marketing Manager & $\begin{array}{l}\text { Co-operative Retailer ('Ethical' focus) } \\
\text { - Local co-operative }\end{array}$ & $\begin{array}{l}\text { Groceries and Fresh } \\
\text { Food }\end{array}$ & High & Empowerment \\
\hline
\end{tabular}


TABLE 2. Practices of Abdication and Activism on the Inside

\begin{tabular}{|c|c|}
\hline \multicolumn{2}{|r|}{$\begin{array}{c}\text { ABDICATION } \\
\text { Reproductive Practice }\end{array}$} \\
\hline $\begin{array}{c}\text { Definitions of } \\
\text { COPING Practices }\end{array}$ & Examples \\
\hline $\begin{array}{l}\text { Distancing from Responsibility: consumer, } \\
\text { organization. } \\
\text { Complying with pre-defined organisational } \\
\text { codes/policies and/or deferring decisions of ethics or } \\
\text { sustainability to distant others in the business — such } \\
\text { as sustainability departments, enables managers to } \\
\text { displace ethical obligation from the level of } \\
\text { individualised workplace practices to the level of } \\
\text { institutional structures. Institutional ethics come to } \\
\text { stand in for personal ethics. Projecting responsibility } \\
\text { for making ethical consumption choices to the end } \\
\text { consumer also enables the management of tensions } \\
\text { arising from inconsistencies between personal ethics } \\
\text { and managerial decision-making. }\end{array}$ & $\begin{array}{l}\text { Consumer: } \\
\text { Informants, such as Tiffany and Deborah, were able to rationalise away feelings of tension by } \\
\text { externalizing responsibility for making ethical choices to the end consumer: } \\
\text { - Tiffany: "I think that ethics and sustainability are becoming more important, or at least } \\
\text { consumers are saying it's more important to them. But is it translating in terms of sales? I } \\
\text { don't really think so. What people say is not always aligned - you take it with a grain of salt, } \\
\text { basically, what people say and how it's going to playout." } \\
\text { - Deborah: "I think for most people it's something they're aware of but... unless it hits them in } \\
\text { the face they're not going to do anything about it." } \\
\text { Organisation: } \\
\text { David and Andreas illustrate the distancing of responsibility for workplace values and ethics to the } \\
\text { organization: } \\
\text { - David: "'We're focused on profit, we're focused on sales, we're focused on market } \\
\text { share...The company has this core value and all of us have to take that into account in the } \\
\text { decisions we make." } \\
\text { Andreas: "We have had to adopt a lot of global principles and processes, including a global } \\
\text { sustainability policy around manufacturing." }\end{array}$ \\
\hline $\begin{array}{l}\text { Externalising Locus of Control } \\
\text { Shifting the location of control over decision making } \\
\text { to external/outside forces-often within in their } \\
\text { workplace or broader market/industry, to render } \\
\text { themselves incapable of enacting anything other than } \\
\text { reproductive practices. }\end{array}$ & $\begin{array}{l}\text { - Melanie shifts her sense of self versus organizational control to cope with situations where } \\
\text { she is unable to make decisions that are aligned with her ethics: "Well at the end of the day } \\
\text { we're a public company and we answer to shareholders. Sometimes we have to make } \\
\text { decisions because we have to make those decisions. So, there's times when you can help stop } \\
\text { it and there's other times where you can't. It's out of your control." } \\
\text { - Colin defers control to the organisation to cope with tensions arising from making ethically } \\
\text { incongruent decisions: "I just follow a process - the company process that they give us - } \\
\text { that's my job and I do it. Then I'm okay because I just put it in the framework and go and do } \\
\text { it, then move on to the next thing." }\end{array}$ \\
\hline Moral Decoupling \& Maintaining Moral Security: & $\begin{array}{l}\text { - Deborah actively separates her ethical frames in and outside of work: "It's quite interesting, } \\
\text { isn't it, because I consider myself to be someone who tries to be ethical in my life, but can } \\
\text { make very convenient excuses for myself [at work]." }\end{array}$ \\
\hline
\end{tabular}


The compartmentalizing of self and work by

maintaining a boundary or distance between self-

ethics and workplace ethics, to enable the

maintenance of a sense of moral security within the

organization and to permanently morally decouple

workplace activities. Thus, alleviating experiences of

tension, responsibility and guilt.
- Tiffany maintains a sense of moral security in her organization-and her decision making within it - by making favourable comparisons with the other organisations: "All the companies that I've worked for - they've all been large scale global organisations - have behaved in an ethical manner, I have no reason for doubts, and we're not doing anything dissimilar to competitors."

- David creates an amoral zone around decision making: "Well, at the end of the day we work for the company, for the company to stay in business and make money, so we're about selling as many [X's] as we can."

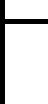 \\ Definitions of \\ Appropriation of Business Resources and \\ Processes: \\ Financial Data, Market Data, Business Cases. \\ The adoption and appropriation of business functions and tools - particularly the instrumental CSR logic- to build commercial business cases that legitimate ethical ambitions. Using the commercial/business case enables the legitimation and the disguise of normative ethical/sustainable motives and makes practices that challenge business-as-usual appear less divergent and threatening.}

\section{ACTIVIST}

Transformative Practice

\section{Examples}

\section{Appropriation of Business Concerns as Trojan} Horses:

Reputational Risk, Commercial Risk.

The exploitation of the key instrumental business concerns around reputational risk and financial risk as a Trojan Horse to gain acceptance for personal normative concerns.
- Scott uses the high negotiation power he wields in buyer-supplier relationships and knowledge of the business resources and processes to overtly pressure suppliers into improving the environmental impacts of their supply chains. For example: "We spend a lot of time developing the house 'Green' brands with our range of [Brand X]. I probably haven't been the greatest advocate for it, because I've been rather disappointed to think we've had to source them from overseas, so I'm in the process of working with suppliers to work out how we can source them locally. All good, but their environmental standards aren't as high as ours. Every product that I carry that's green will have a [certified label] on it. That's the minimum standard we need, and I've been influencing suppliers - and that means that they need to get it".

- Melanie uses her position and legitimacy as the voice of the consumer in her business to present market-data related arguments that support her own sustainability concerns. For example: "I'm always the one saying if we want to play in this consumer market we have to continue to do this. But, it is also the right thing to do, right. It's not just for the sales. It's the right thing to have a product line that has a certified organic, a fair-trade certified."

- Susan plays on her company's concern with reputation to gain approval for her visits to suppliers' production facilities to audit the working conditions and ensure that there aren't any children involved in production — often these visits are unannounced: "That's the reason why management is so supporting in providing us with the finance to go and audit suppliers, regardless where they are around the world. I've been in South Africa. I don't know how many times I've been in China, a couple of times in Malaysia. Twice this year, I was in Thailand and India... So there won't be any bad publicity for [company].'

- Jerome is able to vet and choose suppliers based on ethicality of their practices because his organisation will forego short-term financial gain to minimise reputational risk: "You've just 


\begin{tabular}{|c|c|}
\hline & $\begin{array}{l}\text { got to be on the ball, because if you're not across it, [company] can get caught out. [Many] } \\
\text { times I've been able to knock back a supplier or not award business because, even if it has } \\
\text { been a cheaper and better financial outcome for our organisation, but they haven't achieved } \\
\text { this, this and this. [The company] wants to be absolutely, absolutely beyond reproach." }\end{array}$ \\
\hline $\begin{array}{l}\text { Influencing \& Forming Morality Mediated Praxis } \\
\text { The forming and influencing of morality praxes that } \\
\text { are internal and external to the organization — such as } \\
\text { in-house peer-to-peer groups or industry } \\
\text { communities where peers, mentors and supervisors } \\
\text { physically or virtually coalesce. }\end{array}$ & $\begin{array}{l}\text { - Colin uses his informal influence to attempt to bring his own concerns - such as packaging } \\
\text { waste - into R\&D decision making through NPD forums. Uses consumer/customer data and } \\
\text { business cases to argue his case. For example, "If we can use a brown paper bag versus an } \\
\text { aluminium or a plastic bag, then I will try to influence the team to look at making it in brown } \\
\text { paper bags. I have those conversations all the time, and it feeds back into marketing, } \\
\text { concepts and production. I challenge all the time, like a broken record. I keep having those } \\
\text { conversations because they're important to me and because I feel that if I can have a } \\
\text { thousand of those conversations, maybe one of them will work." } \\
\text { - Patrick exercises both peer-to-peer and managerial influence in interactions and through } \\
\text { communication to influence the broader culture of his organisation: "I think we've been very } \\
\text { effective at creating a culture that makes employees aware of our responsibilities as citizens } \\
\text { of this planet. At every stage I am reminding them of that responsibility. That creates an } \\
\text { awareness internally of doing the right things for the planet and human beings." }\end{array}$ \\
\hline $\begin{array}{l}\text { Instigating Moral Shocks } \\
\text { The orchestration of environments, narratives, and } \\
\text { experiences as 'trigger events' that are designed to } \\
\text { shock the moral sensibilities and unhinge the moral } \\
\text { stabilities of peers, subordinates and superiors. }\end{array}$ & $\begin{array}{l}\text { - Michael instigates moral shocks about the ethicality and sustainability of paper goods } \\
\text { through narrative means: "Basically what I do is tell a story. There's a couple of different } \\
\text { stories that I tell depending on who I'm dealing with. Usually by the time I get to the end of } \\
\text { it, I've been pretty good at opening the door. It's actually remarkably powerful just telling } \\
\text { that story. That definitely keeps the door open and I find I get a lot of my credibility from } \\
\text { that." } \\
\text { Randell uses covert and overt tactics to influence his peers in his organization, from overtly } \\
\text { bringing in climate change experts and vivid imagery to instigate moral shocks, to covertly } \\
\text { drawing on the company's aversion to reputational risk. For example: "I've presented that } \\
\text { [climate change concerns] a few times. For example, I've had a session here where [a] } \\
\text { climate scientist came out and gave the spiel on what's going on, and we had a good turnout. } \\
\text { I factored that into a number of presentations to say, you know, this is one of the issues [if] } \\
\text { climate change happens. I basically pulled all those cuttings, like the more recent ones, like } \\
\text { you know, the Arctic ice cap disappearing, [and] there were another couple that I had there } \\
\text { that were kind of building on it and just saying look there's a real risk that climate change } \\
\text { would come right back onto the agenda". }\end{array}$ \\
\hline
\end{tabular}


TABLE 3. Enabling Conditions of Activist Practice

\begin{tabular}{|c|c|}
\hline $\begin{array}{c}\text { Definitions of } \\
\text { Enabling Conditions }\end{array}$ & Examples \\
\hline $\begin{array}{l}\text { Empowerment \& Psychological Safety } \\
\text { Formal and/or informal agency, fosters a } \\
\text { sense of empowerment in decision making. } \\
\text { Empowered managers feel psychologically } \\
\text { safe to be themselves (Edmondson, 1999) } \\
\text { because they are embedded in an } \\
\text { organizational climate characterized by trust } \\
\text { and respect. Dimensions of this formal and } \\
\text { informal agency included factors such as } \\
\text { positional power, trust and credibility, } \\
\text { knowledge of the business levers and } \\
\text { informal decision-making networks, } \\
\text { connections and personal relationships } \\
\text { within the firm. }\end{array}$ & $\begin{array}{l}\text { - Seamus experiences a culture of empowerment within his organization that engenders a sense of } \\
\text { safety in making ethically congruent decisions: "There are so many different directions you can go } \\
\text { here at our company... All of us personally have our own interest here-there are some people who } \\
\text { are really interested in water quality, you get some people who are really interested in waste } \\
\text { production issues, some people who are really interested in animal welfare issues." } \\
\text { Anastasia states that: "I'm always proud when our company chooses to take a stance on something } \\
\text { that isn't necessarily friendly to immediate bottom line profits." This company stance on the } \\
\text { immutability of ethical principles engenders Anastasia with the sense that she too has the freedom to } \\
\text { make decisions that may impact company profits if doing otherwise has negative ethical } \\
\text { consequences: "I was drawn to work at [company] because I felt like it very closely mirrored my } \\
\text { values. Food is a big area of interest in terms of my belief that it has such a profound impact on our } \\
\text { health and daily outlook. As consumer I do also - because I've worked with a lot of farmers and } \\
\text { understand how hard it is to be a farmer, I really believe in supporting the livelihood of people that I } \\
\text { think have a really tough job and a really strong impact on the planet because so much of our land is } \\
\text { dedicated to agriculture. So, these heavy things go through my mind [when making decisions]." }\end{array}$ \\
\hline $\begin{array}{l}\text { Moral Shock } \\
\text { Moral shocks (Jasper 1997) are critical } \\
\text { junctures in space and time that cause an } \\
\text { irreversible transformation or shift } \\
\text { (Carrington et. al., 2015; Wright et al., } \\
\text { 2012). These events create a deeply felt } \\
\text { shock when the individual realizes that their } \\
\text { own or their firm's business decisions may } \\
\text { have contributed to social/environmental } \\
\text { harms that they find personally abhorrent. } \\
\text { This seismic shock catalyzes an irreversible } \\
\text { shift in their perspective. No longer could } \\
\text { these individuals view their firm, or their } \\
\text { own place within it, as amoral spaces. A } \\
\text { new affective space has been opened up in } \\
\text { which a previously acceptable and } \\
\text { comfortable form of professional life is no } \\
\text { longer tolerable. }\end{array}$ & $\begin{array}{l}\text { - Patrick's experience of moral shock was gradual and triggered by specific issues that he could link to } \\
\text { his children: "When I got to the market [developing country], I realized the incidence of diabetes and } \\
\text { talking at the grassroots level about the impact [our brand] was having. It made me change tack. We } \\
\text { really cannot do this anymore because kids are eating them. We need to do something about it. It's an } \\
\text { inspiration from my own ethics - it made me change." } \\
\text { Philippa experienced a sudden moral shock when a brand that she was managing received a warning } \\
\text { from an external consumer-based auditor for "low general integrity in marketing" due to the poor } \\
\text { negative health effects of consuming the brand and her ethically-questionable advertising strategy that } \\
\text { targeted children: "It was a big wakeup call for me". } \\
\text { Similarly, James' experience of moral shock was triggered when he linked the nutritionally-poor food } \\
\text { that he was pushing to school cafeterias and the health of his own children: "I have two children at } \\
\text { primary school too, so it was very, very close to my situation and I felt it impact me personally." } \\
\text { Melanie's moral shock was triggered by the exposure that her position and company gave her to the } \\
\text { ethicalities of the extended supply chain: "I think [company] has given me the ability to look on the } \\
\text { flip side which is not just is it good for me but is it good for the environment. Is it good for the folks } \\
\text { who grew it. Is someone being harmed on the other side. I think they've really given me the lens of } \\
\text { looking at the bigger picture." }\end{array}$ \\
\hline
\end{tabular}


- Nigel experienced a gradual moral shock when heading-up the marketing function across all 'developing and emerging' markets for his organization: "I've certainly in the last decade gone from being almost exclusively focused on just wanting the best solution for myself and therefore not the planet, to a high degree of awareness." These triggering events gradually accumulated to a tipping point as he viewed first-hand the massive issues of post-consumption waste and general living conditions in many of these countries and regions: "Living and working in the D\&E world changed my view of things. When you go and live in countries where a large proportion don't have safe or clean drinking water, it drives you to think quite differently about your own consumption. I've certainly changed my behaviors and I have a heightened level of awareness."

\section{Morality Mediated Praxis}

Praxis represents the dynamic

interconnection and interaction between individuals, institutions and society

(Jarzabkowski et al. (2007); Sztompka,

1991). In morality praxes, morality is a connective tissue that mediates the interactions of these stakeholders. Two layers of dynamic interaction occur in organizational morality praxis: (1) individual managers influencing other managers in morally charged sites of collaboration; and (2) individual managers interacting with the shifting macro moral expectations of society.

\section{Macro/Micro:}

- Patrick illustrates the interaction of external independent bodies (NGO's), consumers, and his organization at morality praxis: "It was only when NGO's pointed their finger at certain brands that people began to take note. It was only when the trust was breached that people moved away from those brands."

- Seamus reveals macro/micro interactions between managers and their external consumers: "Anybody in sales and marketing should be taking a lot of feedback from their client base. As the clients in any industry become more educated and more concerned with issues about sustainability within their own home or own business or whatever product they're buying they make those demands on companies. If we're not evolving to incorporate answers to their questions about where does this come from, what goes into this, where is being sourced then we're doing a disservice to our company to be at the leading edge."

- James views his moral compass and ethical concerns to be aligned with much of society: "So my ethics, I think that's also playing out with a lot of people." James illustrates the interaction between himself as an individual manager and as a citizen of society at morality praxis.

- Susan reveals the two-way nature of morality praxis in suggests that in terms of leading edge sustainability: "Is it corporate push versus consumer pull that's driving the discussion? I think it's a little bit of both."

- Scott reflects on the interactions of three stakeholders at morality praxes: consumers, suppliers, and his organization; and that these interactions are not always successful in producing a coherent outcome: "it is quite a movement that's out there, purchasing ethically. Still a niche part of the market, but it is a trend that we need to be aware of as a retailer, to work with our supply base to deliver on products that the consumers are looking for. Unfortunately, we don't always join the dots correctly and we're heading in one direction, and the supplier's heading in another, and our consumers are looking for something totally different." 


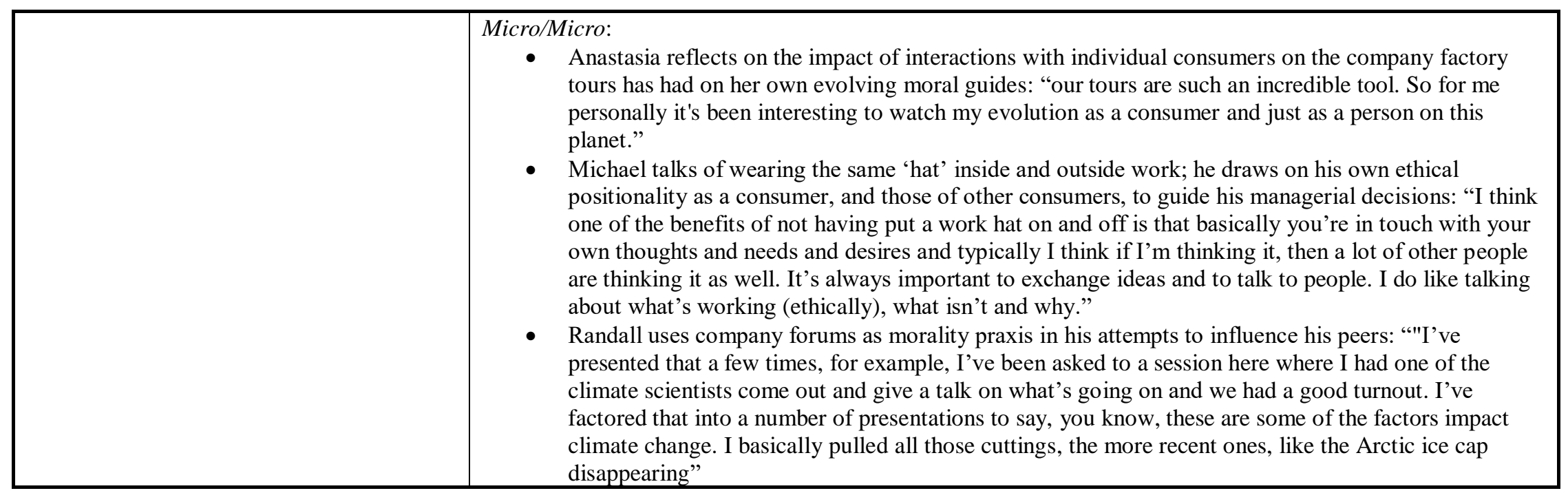




\section{First Order \\ Emic Practice and Concepts}

Second Order

Etic Themes

- Externalised locus of control

- Limited agency: formal and/or informal

- Malleable to the normative expectations and strategy-in-practice of the organization: following the script

- Abdication of responsibility to: (1) organization; (2) end consumer

- Stripping moral dimensions from business decisions and offerings

- Use of rationalization tactics

- Compartmentalizing work and self

- Hidden acts of resistance and activism

- Adopting business discourse and practices for own ethical ends

- Harnessing commercial practices as tools of resistance and change

- Adopting business practices - such as instrumental CSR - for own ends

- Internalized locus of control: internalizing responsibility

- Boundary work tactics to integrate self and personal values into managerial decisions.

- Cherry-picking social causes and issues that are personal passions

- Triggering Moral Shocks: link to societal expectations or own concerns

- Public acts of social and ethical activism

- Top-down influencing of subordinates to change business CSR discourse and practices from the grass-roots up

- Positional power: with power comes responsibility

- Informal agency: with agency comes the ability to 'be myself'

- Embeddedness in the structures and strategies of the organization

- Managerial MO: moral empowerment versus control

- Personal capability evolution: Being ready to 'step-up'

- Deep shock that shatters illusions and creates a new moral lens

- You can't go back, you can't un-know what you now know

- Catalyst to internalize responsibility

- Changing of the guard: new wave of ethically conscious managers

- Grass roots demand from within the organization

- Locus of moral influence: internal (peer) and external (societal)
Regulated practice that

reproduces established

organizational practices

Coping Tacticsto manage dissonance and incoherence

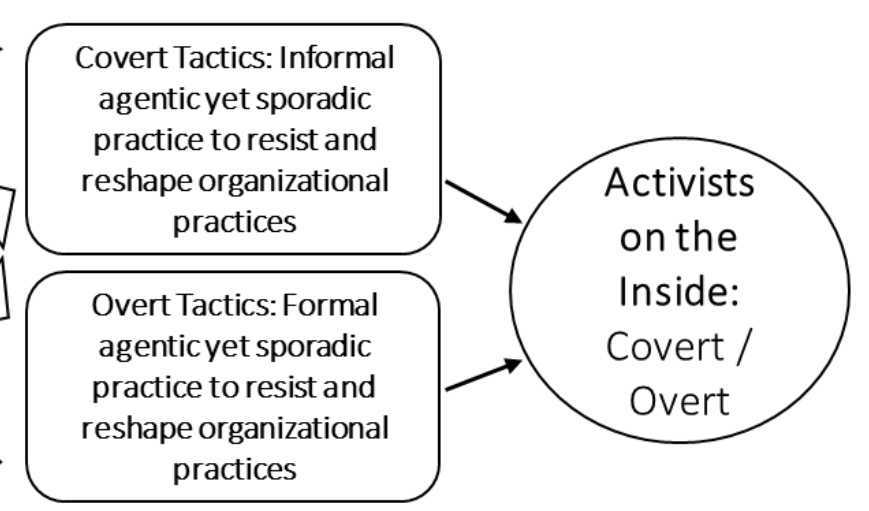

practices

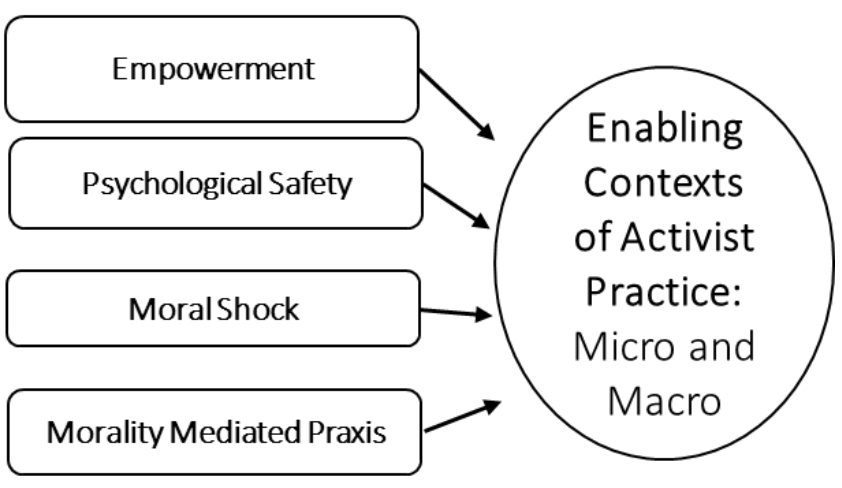

Figure 1. Data Structure 


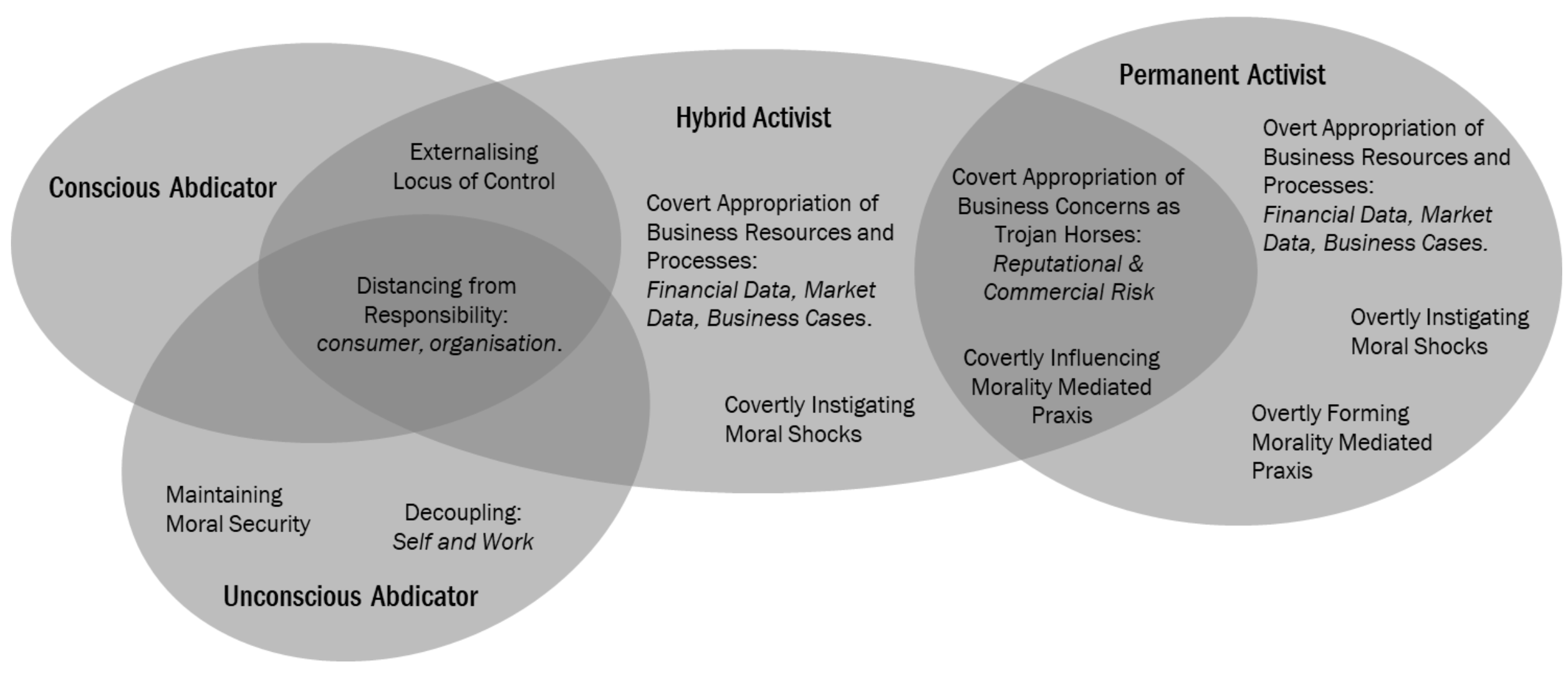

Figure 2. Managerial Practices of Abdication and Activism on the Inside 


\section{MICRO-LEVEL:}

Individual Practice within the Organization

\section{MESO \& MACRO LEVEL:}

Changing Organizational Practices

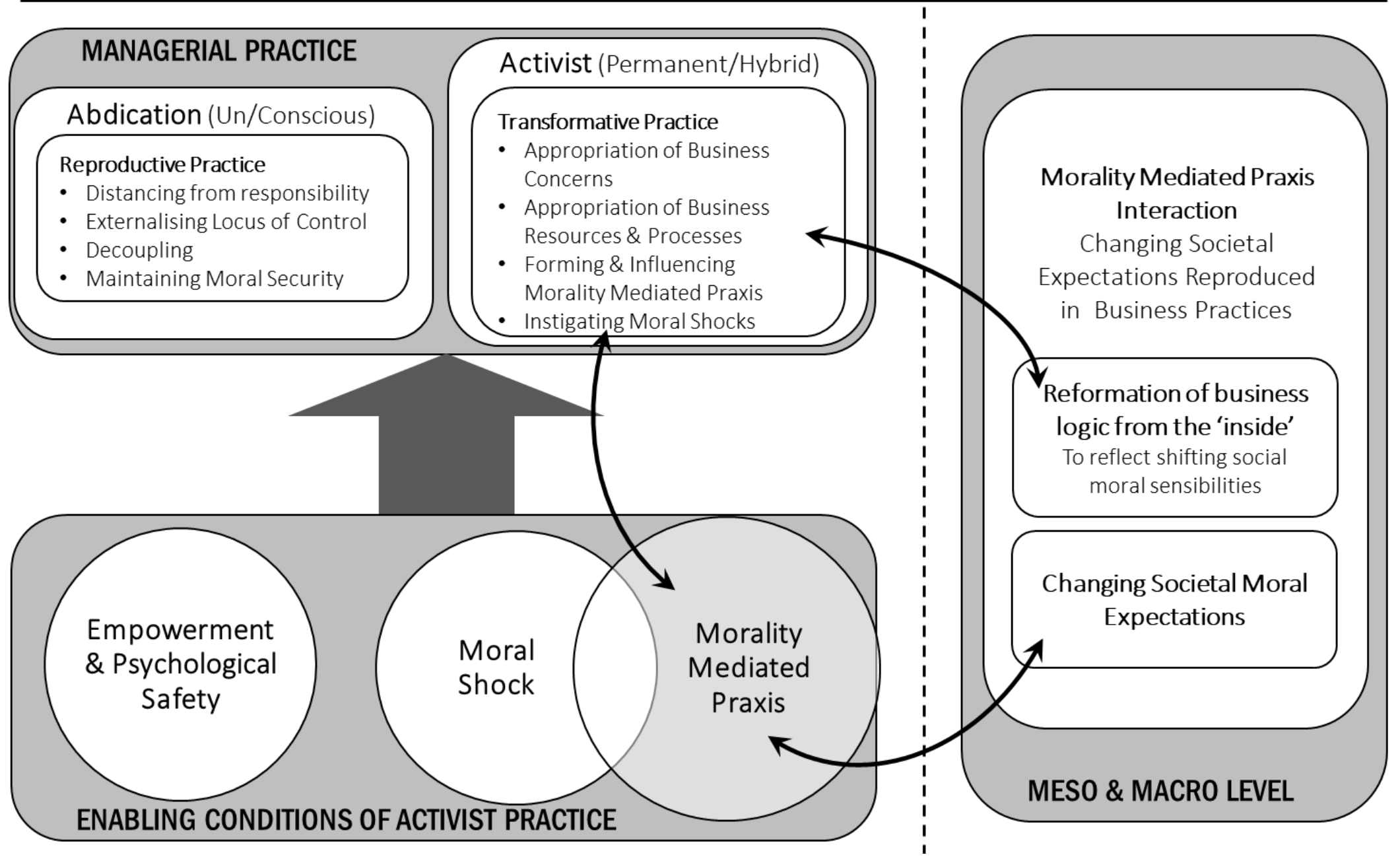

Figure 3. How Micro-level CSR Practices Influence the Reproduction of Macro Societal Change in Meso-level Organizational Practice 